\title{
7. Everyday Cultures and Identities
}

\author{
Christel Baltes-Löhr, Agnes Prüm, Rachel Reckinger, \\ Christian Wille
}

\subsection{Introduction: ON the Reciprocal Relevance OF Everyday Cultures and Identity Constructions}

The main focus of this contribution is on the empiric analysis of interactions in everyday social life. For the purpose of our common research we will investigate the following questions: How are everyday-cultural identities negotiated in the conflicting areas of attributed and appropriated identities? How and why does this identity-based interdependency express itself in everyday life? How are actions and attitudes explained, legitimised and interpreted? These questions are examined by researchers from the viewpoint of their respective disciplines in terms of gender perceptions, 'banal' forms of consumption and social orders.

The everyday practice that we will analyse with the aid of discursive practises (see below) is compounded of collectively shared values, attitudes and standards (Conceptas), as well as modes of perception, belief, evaluation and action as they appear in the course of social interaction (Perceptas) (Bolten 2007). In the results presented below, the collective always resonates in the individual and the individual in the collective, which lends a certain variability and complexity to the examined identities. The defining feature of this interpretation of the identity concept is its pluridimensionality, which does not conflate individuals to rigid categories (e.g., man/woman) but also takes contextual and intersectional affiliations into account (e.g., sociocultural milieus, age groups, affinity groups etc.).

\section{Everyday Cultures Seen from a Praxeological Perspective}

In the following analyses the focus therefore does not lie on ready-made structures of cognitive meaning and sense of 'everyday culture' but on its practical application, which is not to mean what people do every day but rather which self-evidencies and 
irritations in attitudes and activities are shared by the subjects. This is based on the assumption that culture finds its expression in the concrete confrontation with the material and social environment: "Kultur lässt sich [...] erst im Umgang mit Dingen und Körpern wirklich 'dingfest', d.h. sichtbar, aufzeigbar, nachweisbar, nachvollziehbar machen"1 (Hörning/Reuter 2004: 12). This refers to practical contexts in which the cultural aspect expresses itself. In particular, intermediate category forms are significant here, such as "third Spaces" (Bhabha 2000), which are explained under the keyword of ambivalence. The specific conception of culture outlined above will be subsumed under the key term, of 'everyday cultures' with the plural form chosen here, aiming at drawing attention to the parallel and different processes of social interaction and their effects.

The first aspect of this twin term emphasises how close to real life our approach is, which centres on unquestioned "vertraute Selbstverständlichkeiten, eingelebtes Alltagswissen und routinisiertes Alltagshandeln"2 (Hillmann, 2007: 19). Routines, rituals and personalisations should, in this context, not be understood as mechanical, rigid repetitions of everyday attitudes and sequences of events but rather as permanent, minor shifts in the sense of a transformation (Butler 1993; Deleuze 1968) which Derrida denotes with the term "différance" (Derrida 1968). While the shifts referred to here permit individual latitude, they do not dispute the intersubjectivity in action situations. Collective stocks of knowledge can be unsystematic, judgemental and partly contradictory (Schütz 1972), i.e. they may constitute a pragmatic simplification of everyday actions - whereby they combine a certain openness of interpretation with a normative regularity. Despite the capability for intersubjective consensus of everyday knowledge "machen sich infolge sozialkultureller, gruppenspezifischer und biogaphischer Einflüsse individuelle Differenzierungen [...] bemerkbar"3 (Hillmann 2007: 20), which, in turn, have an impact on everyday knowledge.

The second aspect contained in the concept of 'everyday cultures' connects to the cultural-theoretical debate. As suggested above, what is pertinent here is not a normative or holistic understanding of the concept of culture, but rather one that is meaning- and knowledge-oriented (Reckwitz 2001; Reckwitz 2004). This is based on the assumption that different complexes of behaviour emanate, are reproduced and altered against the background of symbolic structures of the social environment, forming the level of the cultural. This notion of culture is continually modified and developed in the social and cultural sciences, which raises the question whether culture is to be understood as a configuration of supra-subjective symbolic structures or as a result of subjective-interpretative performances. This question

1 | Personal translation: "Culture can only be rendered tangible [...] by dealing with things and objects, i.e. it becomes visible, traceable and understandable".

2 | Personal translation: "Familiar self-evidencies, ingrained common knowledge and routine everyday actions”.

3 | Personal translation: "Individual differentiations [...] manifest themselves as a result of socio-structural, group-specific and biographical influences". 
can be addressed with a praxeological synthesis of both perspectives. While useful in revealing culture as a supra-subjective attribution, the structuralistic view does not give sufficient consideration to phenomena of cultural change or subjective appropriation. Here, the conceptualisation of culture as a result of a performance of subjective interpretation proves more effective, for instance when examining the subject's everyday-cultural and innovative appropriations. However, these do not occur disconnected from the socio-cultural circumstances and resources available to the acting subjects due to their different, yet circumscribed positions in the social space, as praxeology implies (Bourdieu 2000 [1972]; Bourdieu 1980).

This contribution adopts the above praxeological synthetic model and views processes of identity-based attribution in the structuralistic sense explained above and appropriation processes and methods as interpretative performances of the subjects. By conflating both perspectives, the dualism of culture as a structure on the one hand, and culture as a subjective performance on the other, can be overcome - as phenomenologically and structurally oriented approaches are married theoretically and empirically. This means that the socio-structural embeddings in the social environment are envisaged simultaneously with the subjective attitudes and actions of the actors. In this sense, a given practice - be it as attribution or appropriation of gender concepts, forms of consumption or societal categories represents a complex of behavioural routines that carry meaning and are subject to change, performed via discursive practices (see below) whose cohesion is ensured by an implicit 'logic of everyday life'. The contributions attempt to reveal these kinds of logic of everyday cultures by tying them up to the practices of the sociocultural milieus of Luxembourg's resident population.

\section{Constructions of Identities as a Social Practice}

A particular feature of identity work performed in everyday cultures in the analysed areas is a certain 'invisibility' since, as a rule, it is not queried in the practice of everyday life and is subject to the pragmatism of concrete action. It is only the interview situation that elicits a reflected verbalisation with regard to the topic in question ${ }^{4}$. It allows insights into subjective worlds of meaning articulated in interactions during the interview. This discursive act as well as its contents of meaning are understood as discursive practices, as defined by Foucault:

II s'agit de faire apparaître les pratiques discursives dans leur complexité et dans leur épaisseur; montrer que parler, c'est faire quelque chose - autre chose qu'exprimer ce qu'on pense, traduire ce qu'on sait, autre chose aussi que faire jouer les structures d'une langue; montrer qu'ajouter un énoncé à une série préexistante d'énoncés, c'est faire un geste compliqué et coûteux, qui implique des conditions (et pas seulement une situation,

4 This does not mean that there is no reflection in everyday life but, rather, that everydaycultural decisions are barely questioned during their implementation. 
un contexte, des motifs) et qui comporte des règles (différentes des règles logiques et linguistiques de construction); montrer qu'un changement, dans l'ordre du discours, ne suppose pas des 'idées neuves', un peu d'invention et de créativité, une mentalité autre, mais des transformations d'une pratique $[\ldots]^{5}$ (Foucault 1969: 272; authors' emphasis).

This means on the one hand that different discourses mutually influence each other and, on the other, that their interactions are performative, so that the individuals - in our case the interviewees - "do something with the words" (Austin 1970). However, the words also 'do' something with them. This interaction is a defining feature of "discursive practice" and makes clear that discourses structure the practices (discursivity of the practices) and, at the same time, practices structure the discourses (performativity of the discourses) (Reckinger 2008). This approach serves to see discourses and practices not as autonomous, sociocultural elements suspended in space, but to draw attention to their constructed relationship.

This raises the question, in terms of methodology, to what extent social practices can be captured with empirical techniques of data gathering. A fundamental distinction has to be made between the various procedures by which social practices become accessible either indirectly or directly. The latter, for instance, includes participatory observations or experimental procedures which imply a controlled framework and, for the interviewees, a certain removal from everyday life. By contrast, surveys, interviews or content analyses permit an indirect access, which favours a verbal approach, making it more suitable for our purposes. In this way it was possible, for instance, during qualitative interviews and quantitative surveys, to enter into contact with subjects that are acting or participating in social practices and to obtain, via their statements, specific information about social practices, their regularity and frequency as well as about their subjective significance. Furthermore, the discourse-practical content analysis enables a reconstruction of different aspects of an action, with the focus being not on the actions themselves but on their performativities. For the purposes of our investigation we have analysed legal texts, information material and statistical data with the aim to reveal evidence of social practices and to draw conclusions regarding the varieties of 'logic of everyday life'.

Aside from the outlined methodological aspect, the identities under investigation and the differentiations made by the subjects require further scrutiny (Reuter/

5 | "It is an attempt to reveal discursive practices in their complexity and density; to show that to speak is to do something - something other than to express what one thinks; to translate what one knows, and something other than to play with the structures of a language (langue); to show that to add a statement to a pre-existing series of statements is to perform a complicated and costly gesture, which involves conditions (and not only a situation, a context, and motives), and rules (not the logical and linguistic rules of construction); to show that a change in the order of discourse does not presuppose ,new ideas', a little invention and creativity, a different mentality, but transformations in a practice [...]" (Routledge translation). 
Wiesner 2008). Dealing with these categories has become more complex in the course of globalisation and liberalisation. Forms of hybridisation or hyphenated constructions put classical theories to the test and undermine binary categories and notions of difference. For instance, the theoretical figures of inter-categorical structures (Reuter/Wiesner 2008) are increasingly being (re)discovered within the framework of poststructuralistic and postmodern approaches as ambivalent contemporary phenomena. What they have in common is the breakdown of binary logic of female/male, good/bad, familiar/strange etc. which are generally used as explanatory categories. Inter-categorical concepts (Bhabha 2000; Welsch 2005; Breinig/Lösch 2006) attempt to register the penetration of pre-established differences and draw attention to "prozesshafte, dynamische, flüssige Vermischungen, die sich nicht ohne weiteres feststellen lassen"6 (Reuter/Wiesner 2008: 132). This state of ambivalence, of 'in between', which defies clear classifications permanently reinvents itself.

The research interest of the present chapter is directed, among other things, at such fleeting moments of ambivalence at the level of everyday cultures. It assumes that the binarity of differences can be broken up within social practices and innovatively reconfigures itself by following an 'everyday logic'. This approach therefore is not about the dissolution of differences but about the transgression of binary categories in everyday culture. The focus thus shifts from the binarycoded logic of "either-or" to the ambivalent logic of "as well as"7, hitherto a largely neglected aspect of the practices of everyday cultures. This shift should not be seen as a substitution but as an expansion, because at the phenomenological level both the reconstruction of binarities and their transgression and reconfiguration can be observed.

It is against this background that the present chapter will look at examples of instances where ambivalence and the related dynamics of identity constructions manifest themselves in the areas of everyday cultures in terms of gender perception, forms of consumption and appropriation of social structures. First, we will attempt to establish the degree of power exercised by gender images and subsequently take a look at the relevance of gender among women and men living in Luxembourg. We will investigate hegemonically effective attribution processes in the context of gender identity constructions as well as individual appropriation processes in their different forms of expression. For this purpose we will examine homogenising or differentiating notions of gender identities against the background of an intersectional foil and explore the relevance of the dichotomy between constructivist and essentialist gender notions. In addition to the question of the relevance of gender in interhuman contact, preferences for different models for reconciling professional and private life will be presented both in relation to each other and

6 | Personal translation: "Processual, dynamic, fluid comminglings that are not easily identified".

7 | See Baltes-Löhr 2006: 70. 
to the respective milieus. Additionally, we will assess the categorial discriminatory power of gender as an analytical category in respect of gender topics of everyday cultures, with their interlacing between attribution and appropriation processes.

A further subject we will address is the standard and the understanding of 'good' food between political model and individual everyday practice. In an initial step, the analysis will focus on an attributive concept of political action which, in its recommendations, attempts to provide a certain health orientation - in a creative, but object-related way. The attention will subsequently move to everyday dietary routines whose forms of appropriation revolve around self-responsibility, action potential and hedonistic pragmatism in a more person-centered perspective. The dynamic interactions between these two types of interpretation of 'good' food create contextual margins for identity constructions.

Finally, the example of cross-border workers in Luxembourg will serve to draw some conclusions about processes of identity construction, in particular concerning the way how cross-border workers are perceived by the Luxembourg resident population, which evinces different forms of construction of this phenomenon. The aim here is to retrace identity appropriations or positions of the Luxembourg resident population in relation to cross-border workers. For this purpose, we will examine inclusion and exclusion strategies used in everyday cultures and determine on this basis the status of the cross-border workers in the Grand Duchy. In a second step, we will assess which conclusions we may infer about processes of identity formation from the partly ambivalent appropriations revealed here.

\subsection{Permanent Performances: Gender in Motion}

This part of the study will investigate the impact of gender representations. Which are the prevalent gender representations among women and men living in Luxembourg? Assuming the construction processes of attributed gender identities via hegemonic gender discourses, the investigation primarily seeks to explore processes of appropriation of gender identities and gender representations in the context of intersectionality. Here, two questions come into play that have guided our research: first, to what extent are dualistically connoted differentiations between essentialistic and constructivist gender representations mirrored in the empirical material, and second, can gender still be considered as an analytical category with a selective discriminatory power? In other words, to what extent does the category of 'gender' play an important role in the analysis process of the interviewees' responses?

Based on the data supplied by a representative study and 27 semi-structured interviews, we analysed performances of femininity, masculinity, homo- and transsexuality. The analysis also included the importance of the category of 'gender' in processes of social interaction, as well as assessments regarding gender equality and gender discrimination in Luxembourg. In addition, we examined the gender models favoured by interviewees in terms of the assumed potential of these models 
for a better work-life balance, and finally the extent of the respondents' awareness and knowledge of gender-related national legislation and campaigns ${ }^{8}$. The following paper is based on the evaluation of four statistical item sets comprising a total of 22 items as well as 290 interview sequences from 27 female and male interviewees.

\section{Theoretical Framework}

Identities, including gender identities, are understood as results of pluridimensional, intersectional and performative construction processes (see McCall 2005; Hirschauer 2001; Klinger/Knapp 2005; Baltes-Löhr 2006: 66). Besides the category of 'gender' - for many years considered as the social structural category par excellence - and the body-related biological category 'sex', also ethnic and socio-economic aspects as well as age become more and more important for such identity construction processes' . Regardless of the number of 'sections', the significance of the category 'gender' is put into perspective by its intersectional contextualisation and could be considered as dedramatised.

Besides their intersectional constitution, identities can be regarded as snapshots of constantly shifting and changing performative construction processes. Notwithstanding all fluidity and changeability, certain aspects of identity seem to evaporate, while others deposit themselves either in the hegemonic discourse or in everyday individual practice. Performative construction processes as well as performative actions (Butler 1993: 123) generate their subject, thus also identities, through naming, enactment and repeated presentations in time and space. Such recurring performative actions have the potential to consolidate that what is repeated. They may also lead to the discursive deconstruction of prevailing notions creating a diversification of binary patterns, by for instance producing different facets of gender identities.

If the potential to reveal multiple aspects of a given subject is inherent to repetitions and thereby enables dualistic hierarchies to change, shift and dissolve, then one can assume that repetitions have dehomogenising and heterogenising effects. Differences are given space. At the same time, similarities can become

8 | For this purpose we examined and analysed, concurrently with this research project, legislation passed in Luxembourg since the end of the 1960s on the subject of gender equality and equal rights. The findings of this document analysis have been published in a publication dedicated to this subject and receive only cursory treatment here. Baltes-Löhr, Christel and Susanne Stricker. Eine Untersuchung der luxemburgischen Gesetzgebung in Bezug zur Konvention CEDAW und dem ihr implizierten Gleichstellungsprinzip. Luxemburg 2009.

9 | There are different opinions about which 'other' categories are significant in terms of identity constructions. Knapp (2005) adds "race" and "class". Lutz/Wenning (2001) identify thirteen categories of difference, while at the same time pointing out that this list is not exhaustive. McCall (2005) mentions "gender", "race" and "class" and adds the category of "region"; Baltes-Löhr (2009) adds the category of "physical constitution". 
visible and be reinforced. Novelty or 'the new' therefore always originates in relation to something else, usually to 'the old', 'the established' and 'the familiar'. Novelty emerges out of processes of slowly shifting changes.

Just as cultural pluralism and cultural differences can be identified not only between cultures but also within cultures (Kumoll 2006: 86) the same can also be assumed for identity constructions. It is important to understand the process of "becoming minor" (Deleuze following Rölli 2006: 39) as a rule of differentiation. This means understanding actually existing features, which are used to identify cultural attributions, as effects of a prior attribution of meaning. Such conceptions of "becoming minor" distinguish themselves from the idea of otherness and of not being identical, which carries an essentialist connotation. Hegemonic identity attributions can therefore be dismantled or deconstructed if the processes of 'becoming minor' are emphasised, so that established, self-evident or even seemingly natural structures of the majority and by extension frequently also of power, as understood by Foucault, can appear to be contingent and as such changeable (Rölli 2006: 40).

As with the different cultural representations, "in-between" spaces or "third spaces” (Rutherford 1990: 207-221; Chambers 1996: 78; Gregory 1997: 228) are of particular significance for articulations of identitary minorities or minority positions. If we can say, with Bhabha, that "Kulturen [sind] zwar durch das Begehren nach Stabilität und Determination, beispielsweise im Sinne einer Nation, gekennzeichnet [...], müssen aber gerade in der Instabilität, der Gleichzeitigkeit von inkommensurablen Geschichten (Narrativen und Historizitäten) und Orten gedacht werden"1० (Bhabha following Bonz/Struve 2006: 141), then this applies equally to identity construction processes. A typical feature of identity constructions is their differentiatedness. Identities become an arena for negotiations and expressions. However, identities and identitary subjects do not necessarily merge but can be different. Thus apparently homogenous identities can contain identitary differences. Just as Bhabha argues against a multiculturally-oriented cultural diversity and in favour of cultural difference, which takes account of the cultural antagonisms, contradictions and incommensurabilities (Bonz/Struve 2006: 149), so can accepting identitary differences (constructivist approach) better accommodate contradictions and contrasts actually lived and perceived than can searching and striving for homogeneous, identitary identities (essentialist approach).

10 | Personal translation: "While cultures are typified by a desire for stability and determination, for example in the sense of a nation, it is [...] precisely in terms of instability and the concurrence of incommensurate stories (narratives and historicisms) and places that we have to conceive of them". 
Our analysis will therefore address the following questions:

- Which homogenising or differentiating ideas of gender identities are recognisable alongside other intersectional components?

- How relevant is the constructivist versus essentialist dichotomy?

- How significant is gender in processes of social interaction and what reactions are there to otherness and others?

- Which models are favoured in terms of a work-life balance?

- What specific knowledge is there about provisions and legislation relating to the equality of women and men?

\section{Resistant Remnants. To which Extent are Essentialist Gender-related Performances still Operating Today?}

The representative study shows that $90 \%$ of the interviewees agree with the assumption that there is a natural difference between women and men. At the same time, $77 \%$ assume that female and male behaviour is learnt during the course of life. $96 \%$ of all interviewees emphasise that women are just as capable as men of taking on leadership functions in society. This indicates that the frequently invoked and elaborated divergence between essentialism and constructivism does not exist as the presumed binary dichotomy, but that both attitudes can coexist.

The markedly high approval rating for the assumption of gender-independent capabilities in terms of taking on leadership positions comes along with the finding that only $56 \%$ of the interviewees believe that the supposed equal professional opportunities for women and men in Luxembourg are also actually exploited in the same degree. This indicates that a factual gender disparity within Luxembourg's labour market is still considered to be a significant discriminatory factor between women and men. This is also confirmed by the interviewees' statements: gender discrimination is primarily perceived in the under-representation of women in leadership positions and in salary inequalities.

The findings are interesting in terms of women's and men's response patterns. Men assume a natural difference between the genders significantly more often, which is more indicative of an essentialist position. This correlation was first seen for Luxembourg in the study: "Bedeutung des Geschlechteraspektes für die berufliche und persönliche Entwicklung/Biographie von zukünftigen Erziehenden und Lehrenden"11 (Baltes-Löhr et al. 2005: 87).

11 | Personal translation: "Significance of the Gender Aspect for Professional and Personal Development/Biography of Future Educators and Teachers". A complete census carried out in March/April 2003 among students and/or pupils of the former ISERP (Institut Supérieur d'Etudes et de Recherches Pédagogiques) and of the secondary level teacher education at the CUNLUX (Centre Universitaire de Luxembourg) and at the former IEES (Institut d'Etudes 
In the present study, significantly more women than men agree with the assumption that both genders are equally suited to taking on leading functions in society. On the other hand, significantly fewer women hold the view that both genders exploit professional promotion prospects to the same extent. This is supported by the fact that considerably more women are prepared to hold back their careers so as to be able to reconcile work and family better. Here too, it is worth reviewing the results of the above-mentioned study, namely that "bei tatsächlich stattgefundenen Einstellungsveränderungen scheinbare Resistenzen bei Frauen und Männern “übrig bleiben”'12 (Baltes-Löhr et al. 2005: 85).

In the current study we see such 'resistant remnants' in the fact that significantly fewer men believe women to be equally suited for leadership positions, i.e. that, from a male perspective, men are still more likely to be better suited for professional life and for executive positions in particular. These findings are reflected in men's perceptions of existing discrimination at the work place as well as in male attitudes towards their own private lives. In contrast to women, men are more likely to assume that female colleagues today are not subject to discrimination in the professional field and, on the other hand however, are significantly less often prepared to curtail their own professional activities to achieve a better balance between work and family life. A glance at the figures indicating the percentage of fathers taking up the option of paternity leave in Luxembourg shows that these attitudes and preferences still reflect lived realities. Whilst the proportion of men taking paternity leave in 2002 was $13 \%$, it increased to $22 \%$ in 2006 . Just as it was summarised in "Bedeutung des Geschlechteraspektes für die berufliche und persönliche Entwicklung/Biographie von zukünftigen Erziehenden und Lehrenden" that "Frauen kritischere Haltungen gegenüber Traditionalismen einnehmen"13 (Baltes-Löhr et al. 2005: 86), in the current case too, it appears that it is again the women who, more so than men, have cast off traditional notions of gender roles. Women exhibit 'resistant remnants' of socalled traditional notions primarily in matters concerning the responsibility for reconciling work and family life while for men they appear in the form of more naturalistic concepts of an essential difference between the genders and men's greater aptitude for professional life.

The interview responses cover the whole range of opinions on socially perceived gender relations, from: "Es ist gut so, we es ist, und es soll sich nicht ändern"14 to "Wir sind im Wandel und auf einem guten Weg"15 all the way to "Es geschieht zwar etwas,

Educatives et Sociales) including educator and social education worker training and studies (Educatrice graduée/Educateur gradué).

12 | Personal translation: "Notwithstanding actual changes in attitude, an apparent resistance among women and men still remains".

13 | Personal translation: "Women adopt a more critical attitude toward traditionalisms".

14 | Personal translation: "Things are fine as they are and nothing should change".

15 | Personal translation: "We are in a period of transition and are heading into the right direction". 
aber Gleichberechtigung oder Gleichstellung der Geschlechter bleiben unerreichbare Utopien"16. Both women and men of various ages emphasise that there are changes within the labour market, that more and more women are obtaining good educational qualifications and are working, and that increasing numbers of men are taking paternity leave.

\section{Competence, Performance and Remuneration Discourse}

What clearly emerged in the survey is a 'discourse of competence'. During the interviews it was repeatedly stressed that whether someone is suited for a given profession is more a matter of competence and performance quality than of gender. Competence matters, irrespective of gender, skin colour, nationality and age. Performance matters. The following point was emphasised during the interviews: just as men earn respect based on their commitment and achievements, so too should women. This discourse reflects two notions: first the image of the "defizitäre

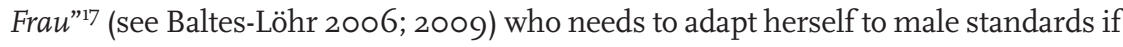
she wishes to attain the same recognition as a man, and second the assumption that housework is something intrinsically unattractive. According to many interviewees, a lot of men would find it "uncool" to say that one is a househusband who hoovers the house and this, allegedly, is why a lot of men do not actually do any housework. Interviewees repeatedly point to wage inequality as a clear case of discrimination. While competence, quality of work and performance all tend to be regarded as a basis for social recognition and status applicable to both sexes, unequal payment remains an indicator of the fact that discrimination against women persists. The interviewees often interpret the economic independence of women as a sign of emancipation.

Essentialist concepts of femininity and masculinity can be found in statements on the supposedly fundamentally different kinds of work performed by women and men. A drastic example: women, it is argued, cannot not perform certain tasks involving physical exertion as well as men and therefore unequal payment is justified. If, the argument continues, women "are as strong as men", they would still remain less efficient than their male colleagues. This quasi essentialist gender difference is then related to the hierarchical structure of the workplace: after all, it is argued, labourers, bricklayers and foremen on the building site are also paid differently.

\section{Otherness and Resistant Remnants}

The interview statements reveal further types of 'otherness': while for men image cultivation, stressing their own importance and relevance, takes precedence over actual activity, women are experienced and represented as being more subject-

16 | Personal translation: "Something is happening but equal rights or gender equality remain unattainable utopias".

17 | Personal translation: "Deficient woman". 
focused and object-oriented. Women in leading positions are often perceived as being specifically female, meaning soft, empathetic etc., and therefore different to male bosses, or else it is assumed that they would have to adapt to the male style. The latter is linked to the concept that gender behaviour can be situation dependent, can be learnt and can therefore also be changed. However, the assumption that there is something such as a "specifically feminine (female) boss" points to the existence of a deeply-rooted essentialist concept of gender: women are still thought of as being stereotypically feminine even within so-called masculine domains. This particular mind set continues to be in full operation where the perception of working women is dominated by the notion of stereotypical intrinsic femininity. Here, once again, there is evidence of 'resistant remnants' whenever essentialist ideas of gender are not broken down by emancipatory changes like increasing female employment rates. Essentialist discourses therefore appear to be more powerful than factual changes in professional life and politics. To discover exactly how these effects are constructed i.e., how they are produced performatively through repetition, alterations, shifts as well as consistencies and resemblances, requires further research.

What is evident, based on the current data, is that to some extent women also remain fixed in their traditional attitudes. For instance, some interviewees stress that women have prevented an equal interaction between the genders by not trusting men to be able to "manage the housework". Employment is often, but not always, seen as a token or even the symbol of emancipation. According to some interviewees, women wishing to adhere to traditional roles want to be respected nevertheless. We can, however, say that the majority of interviewees assume that there are more women working in a job than there are men who are actively involved in the household, and in the care and education of children. Therefore, it can be assumed that the permeability between the traditional 'gender domains', the porosity of gender boundaries ${ }^{18}$ from the so-called female into the so-called male domains seems to be more pronounced than boundary crossings by men into socalled female domains like household, care and education.

\section{Handling 0therness and 0thers}

\section{The Relevance of Gender in Social Interaction}

Based on the concepts of intersectionally and pluridimensionally constitutedidentities which change across time and space through ongoing construction processes and can be described as the results of permanent performances, our analysis examined the significance of cultural background, professional position, age, gender, religion as well as sexual orientation in the framework of social interaction.

18 | Albeit the image of porosity would, at first sight, seem to suggest a uniform fluidity and permeability from $A$ to $B$, this image is modified here inasmuch as the respective openings of the permeable pores should be viewed as being variously sized and pronounced. 
It was shown that gender comes in second last position, followed only by religion, which seems to be even less important in social interaction. Age and cultural background are most important, followed by professional position and sexual orientation. Gender is particularly important to men when interacting with others. For Italians living in Luxembourg, as well as for those with only a lower school education, gender is also significantly important in social interaction. Sexual orientation is mainly of importance to men, interviewees of Portuguese origin, those with lower school education, the unemployed as well as to pensioners. In terms of age, occupation, marital and civil status, there are no significant findings in the response behaviour of the interviewees. The relevance of gender $(27 \%$ approval) and sexual orientation (34\% approval) plays the greatest role within the underprivileged milieu. Within the alternative milieu, gender (9\%) is considered the least significant. In interaction with others, sexual orientation matters to a mere $5 \%$ of the interviewees within the status-oriented milieu.

\section{Homosexuality}

$65 \%$ of all interviewees consider homosexuality and heterosexuality equivalent. The significantly highest approval rates are found among the women (74\%) in comparison to the men (57\%), among the 21 to 29 -year-old interviewees of German nationality, among students and people living in de facto marriage/civil union partnerships ${ }^{19}$. Acceptance of the equivalence of homosexuality and heterosexuality is highest (78\%) within the status-oriented milieu, and lowest within the privileged conservative milieu (54\%).

During the interviews, some of the respondents stated that they had never before thought about this topic. One interview partner preferred not to make a statement because he said of himself that he had a "racist" attitude towards this issue, which he nonetheless subsequently elaborated upon. To his mind, homosexual people were not normal and homosexuality threatened the further existence of mankind: "Wenn alle so wären, dann würde es keine Kinder mehr geben". ${ }^{\circ}$ This statement shows how the minority status of homosexuals is constructed through homogenisation "if everybody was like that" - in conjunction with generativity. The same goes for statements to the effect that a homosexual person always feels that he/she does not conform to the default paradigm that women and men were made for each other. In the majority of interviews, however, respondents confirmed that in terms of approaching homosexuality and homosexuals in Luxembourg, something had changed and that the 'other' is met with greater tolerance. However, the increasing official acceptance did not always correspond to unofficial opinions and attitudes.

19 | The legislation pertaining to registered partnerships also enabled marriage-like partnerships between same-sex couples (Legislation from 09.07.2004). Those who have registered such a partnership (Pacte Civil de Solidarité - PACS for short) will in the following be referred to as de facto marriage/civil union partners.

20 | Personal translation: "If everybody was like that then there would be no more children". 
The establishment of a de facto marriage/civil union partnership model for samesex couples (PACS) had not fundamentally changed this: “Die Bevölkerung schaut aber immer noch schief'. ${ }^{21}$ Homosexuals are still regarded as 'others', as different and therefore queer. The term 'gay' is still a serviceable swearword. This reflects a hegemonic, heteronormative discourse of normality, in which the focal object is considered as "das Nicht-Normale"22 (Knapp 2010: unpublished speech delivered during the inaugural meeting of the Fachgesellschaft Geschlechterstudien ${ }^{23}$ in Berlin, 29/30th January 2010; Jakobson 1971). It is often emphasised that knowing homosexual people helps to break down existing prejudices. Some interviewees consider homosexuality to be a form of discrimination "from the outside". They assume that it takes a great deal of self-confidence to "come out": "Wenn der Homosexuelle die Homosexualität als Normalität betrachtet, dann kann er sich outen, wenn er sich nach der Familie oder den Freunden richtet, dann nicht" ${ }^{24}$. However, an understanding for the fear of coming out is also justified quantitatively: "Weil das eine Ausnahme ist" 25 . This conflates the fear of coming out with a supposed minority status while it is also stressed that homosexuals do not necessarily consider themselves a minority. Quantitativity as a self-evident fact of majorityoriented democracies, often seems to coincide with a rather poorly developed understanding of or weakly developed tolerance for minorities (protection of minorities): the majority counts and is therefore also right. In the final analysis, the 'others' are required to fit in or remain marginal. Differentiation-competent tolerance and acceptance are often lacking, as is sensitivity for the fact that both the owness and the collective subject in the majority position is the non-owness for the marginalised others. Gay men are described as more sensitive people, not only in comparison to other men, but also - and this is noteworthy - to women. This transcends the traditional, essentialist notion of the duality of gender in that sensitivity is not, as it were, attributed automatically to women per se as an essential behavioural disposition. Although none of those interviewed called him/herself homosexual or lesbian, some interviewees explicitly called the notion of gender normality itself into question; uncertainties are admitted and some concede: "Wer weiß schon, was normal ist?"26.

The extent to which liberal attitudes can go hand in hand with ethnically connoted discrimination is shown by the statement of one interviewee who believes that today's society is much more liberal in its approach to homosexuality and

21 | Personal translation: "But the populace still looks askance at it".

22 | Personal translation: "The non-normal".

23 | Personal translation: "Gender Studies Association”.

24 | Personal translation: "If the homosexual person herself regards homosexuality as the norm, she/he can come out; if he/she orients him/herself on family or friends, then he/she can't".

25 | Personal translation: "Because that [meaning homosexuality] is the exception".

26 | Personal translation: "Who can say what is normal, anyway?". 
homosexuals: "Heute ist alles liberaler, außer vielleicht bei den Portugiesen, die noch Angst haben, mit ihren Eltern darüber zu sprechen" 27 . Here too it can be seen how easily even democratically motivated majority discourses construct minorities and assign them a marginalised status and how closely tolerance and discriminatory attitudes can be aligned.

\section{Transsexuality}

$75 \%$ of those questioned do understand that there are people who do not feel comfortable in their gender role and $52 \%$ can understand people who wish to change their sex. Among the status-oriented milieu, an understanding for people who do not feel comfortable in their gender roles is very marked, at $80 \%$, as is that for transsexuals, at $73 \%$. This value is lowest in the petty bourgeois milieu. However, even within this group $70 \%$ still show understanding for not feeling comfortable in the gender role. At $43 \%$, sympathy for transsexuals is significantly lower.

The following table shows the significantly highest and/or lowest values:

\begin{tabular}{|c|c|c|c|}
\hline Categories & $\begin{array}{l}\text { Highest Approval } \\
\text { Rating }\end{array}$ & Item & $\begin{array}{l}\text { Lowest Approval } \\
\text { Rating }\end{array}$ \\
\hline $\begin{array}{l}\text { Gender } \\
\text { Nationality } \\
\text { Age } \\
\text { Education } \\
\text { Occupation } \\
\text { Type of employment } \\
\text { Family situation } \\
\text { Civil status }\end{array}$ & $\begin{array}{l}\text { Women } \\
\text { n.a. } \\
45-59 \\
\text { n.a. } \\
\text { n.a. } \\
\text { Housewife/ } \\
\text { househusband } \\
\text { n.a. } \\
\text { de facto marriage/civil } \\
\text { union partnership }\end{array}$ & $\begin{array}{l}\text { Understanding for } \\
\text { discomfort with } \\
\text { the gender role }\end{array}$ & $\begin{array}{l}\text { Men } \\
\text { n.a. } \\
\text { 6o plus } \\
\text { n.a. } \\
\text { n.a. } \\
\text { Other work } \\
\text { n.a. } \\
\text { Widowed }\end{array}$ \\
\hline $\begin{array}{l}\text { Gender } \\
\text { Nationality } \\
\text { Age } \\
\text { Education } \\
\text { Occupation } \\
\text { Type of employment } \\
\text { Family situation } \\
\text { Civil status }\end{array}$ & $\begin{array}{l}\text { Women } \\
\text { German } \\
\text { 30-59 } \\
\text { University } \\
\text { Housewife/ } \\
\text { househusband } \\
\text { Housewife/ } \\
\text { househusband } \\
\text { n.a. } \\
\text { de facto marriage/civil } \\
\text { union partnership }\end{array}$ & $\begin{array}{l}\text { Understanding for } \\
\text { transsexuals }\end{array}$ & $\begin{array}{l}\text { Men } \\
\text { Portuguese } \\
60 \text { plus } \\
\text { Lower school } \\
\text { Pensioner } \\
\text { Unemployed } \\
\text { n.a. } \\
\text { Widowed }\end{array}$ \\
\hline
\end{tabular}

Table 1: Views on/attitudes towards transsexuality (n.a. = not applicable).

27 | Personal translation: "Today everything is more liberal, except maybe among the Portuguese, who are still afraid to discuss it with their parents". 
Here, two things emerge: the responses regarding understanding for discomfort with the gender role show no significant results in respect to nationality, education, occupation and family situation, pointing to the fact that responses are equally distributed across these categories. It is women, those aged between 45 and 49, those who are homemakers and those living in de facto marriage/civil union partnerships, who show the highest significant approval rating.

We can observe a stronger polarisation in the response behaviour when interviewees were asked about showing understanding for transsexuals. Only with regard to the family situation are there no significant answers. Again, it is women, 30 to 59-year-olds, German nationals, university graduates, homemakers, as well as those living in de facto marriage/civil union partnerships, who approve strongly. The lowest approval rating to these questions, above all concerning the attitude towards transsexuals, can be found among men, over 6o, lower school graduates, the widowed, pensioners and the unemployed.

In the interviews nobody referred to themselves as transsexual. Only three of the interviewees reported knowing transsexuals. Some stated having acquaintances who know transsexuals, others had vaguely heard of them and some reported having seen something about them on television documentaries. One interviewee remembered a female classmate in secondary school who looked like a boy and thought this could be somebody who later became a boy. She mentioned how deeply uncertain everyone at school was at the time, approximately 15 years ago, about how to approach the girl. Generally, in the interviews, transsexuality was closely associated with homosexuality or was associated with, for instance, breast enlargement. It was often mentioned that, due to the uncertainty about how to approach transsexuals, these are frequently subjected to ridicule. Interviewees repeatedly emphasised the importance to immediately consult a psychologist or doctor at the first signs of transsexual behaviour. Alongside this tendency to pathologize, there were also calls for tolerance while underlining the fact that this is easier in theory than in practice.

During the interviews, we also asked how the interviewees would approach a child who did not feel comfortable in his/her own gendered body. The answers indicate a lack of knowledge, helplessness as well as insecurity in approaching such a child. Some of those interviewed said that this would perhaps/hopefully only be a passing phase: "Wenn es sich wieder einrenkt, ist es eben gut" ${ }^{28}$. With regard to adults, however, other interviewees believe that it would be absolutely necessary for those who would like to change their sex to do so, because remaining in a state of such discontent can also make you ill.

The subject of transsexuality, like homosexuality, is still associated with fear and is regarded as a blow of fate. The further the subject penetrates into people's private lives, the more of a threat it appears to become. A line of demarcation is set up between the genders when interviewees repeatedly stress that men have more

28 | Personal translation: "If it straightens itself out again, that would be just great". 
issues with this subject than women. But it is also stated that it might be a challenge for mothers should their boy prefer to be a girl or vice versa. The latter would be more difficult for the mother to understand: after all, she herself is content to be female. This reveals the relevance of identification with one's own gender. If this is called into question, irritations arise. For instance, one interviewee stressed that a father would have a greater issue with the outing of a homosexual son than would a mother, because he is a man.

\section{Gender Models}

\section{Favoured Gender Models: Egalitarian Role Distribution - As Long as There Are No Children}

Attitudes towards different gender models were determined using the following questions:

Which work distribution model within a life partnership do you consider best?

A. The man works full-time, the woman is not employed and she takes care of the household and family

B. The man works full-time, the woman part-time and she takes care of the household and family

C. Both partners share work, household and family chores equitably

D. The woman works full-time, the man part-time and he takes care of the household and family

E. The woman works full-time, the man is not employed and takes care of the household and family

The individual models received the following approval ratings:

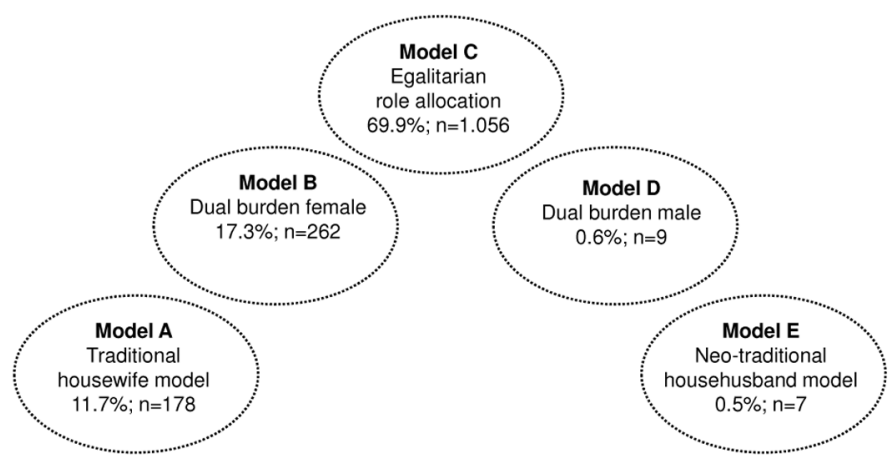

Figure 1: Approval ratings for the models A-E in \% and absolute numbers of respondents. 
Because it is not possible to calculate the statistical significances for models D and $\mathrm{E}$ due to the low number of answers $(\mathrm{n}<30)$, we shall, in the following paragraphs, briefly outline which groups of people responded to these most often: model D is primarily endorsed by young, single students or those living in partnerships with or without children, in households of 3-5 people, possibly in shared accommodation close to town or in the parental home and of French origin. Those who endorse this model come from all income groups except that of $€$ 5,000-7,000 and are most strongly represented in the alternative milieu. Astonishingly, model E is primarily endorsed by the over 45 -year-olds, by people without children, people who are widowed or those living in 1- or 2-person households in rented or owned accommodation. People with a household income of $€$ 4,०००-5, ००० are most likely to endorse this model, as are members of the hedonistic milieu.

The frequency with which model $\mathrm{C}$ is named is quite surprising, since it unambiguously advocates an egalitarian division of tasks between the genders. The response behaviour of women and men does not differ significantly in relation to models A, B and C. We can therefore say that differing gender models are represented in distinct profile whereby it is, however, not possible to demonstrate that the gender of the interviewee is a discriminating category. This indicates that concepts relating to different gender models are not (re)produced through gender affiliation itself but that there may be other categorisations that have a greater bearing on gender models. Among other things this means that, when it comes to explaining existing representations of questions of gender, it may seem appropriate to follow an intersectional approach.

Childlessness seems to raise the approval rating for the egalitarian model amongst both those living in partnerships and those living alone. Put differently, as soon as children appear within a relationship, the approval rating for egalitarian partnership and occupational models decreases. It is easier to endorse gender equality when not confronted with the actual reality of bringing up children. Parenthood/childlessness, therefore, play no insignificant role in the context of identity attribution and appropriation processes, and should be included in the intersectional canon.

While there are clear differences in response behaviour with regard to models A and $\mathrm{C}$, the percentage spread of response behaviour for model B is small. From this one can conclude that this model of a dual burden for the woman is most readily accepted by a broad segment of the population across all categories such as age, school education etc.

Although model $\mathrm{C}$ - the egalitarian distribution of tasks - meets with the highest approval rating, only $51 \%$ of all interviewees state that they themselves would be willing to curtail their professional activities, for instance to better be able to balance their family and work commitments. Even though gender was not revealed to be a significant factor in response behaviour in terms of endorsing model $\mathrm{C}$, it is nevertheless the case that significantly more women are prepared to curtail their own professional ambitions to achieve a better balance between work 
and family life. The following table provides an insight into the highest and lowest approval ratings for models $\mathrm{A}, \mathrm{B}$ and $\mathrm{C}$ :

\begin{tabular}{|c|c|c|}
\hline Highest Approval Rating & Models & Lowest Approval Rating \\
\hline $\begin{array}{l}\text { Over 6o-year-olds } \\
\text { Luxembourg nationality } \\
\text { Partnership with children } \\
\text { Widowed } \\
\text { Helping members of the } \\
\text { family } \\
\text { Lower school graduates }\end{array}$ & $\begin{array}{l}\text { Model A: } \\
\text { Traditional housewife } \\
\text { model }\end{array}$ & $\begin{array}{l}\text { 20-29-year-olds } \\
\text { French nationality } \\
\text { Single without children } \\
\text { Separated, single, living } \\
\text { in de facto marriage/civil } \\
\text { union partnership } \\
\text { Students, freelancers } \\
\text { Public officials } \\
\text { Etudes Supérieures }\end{array}$ \\
\hline $\begin{array}{l}\text { All age groups except } \\
\text { 20-29-year-olds } \\
\text { Italian nationality } \\
\text { Partnership with children } \\
\text { Living in de facto } \\
\text { marriage/civil union } \\
\text { partnership } \\
\text { Employees } \\
\text { Other educational levels }\end{array}$ & $\begin{array}{l}\text { Model B: } \\
\text { Dual burden for the } \\
\text { woman }\end{array}$ & $\begin{array}{l}\text { 20-29-year-olds } \\
\text { British nationality } \\
\text { Single without children } \\
\text { Single } \\
\text { Students } \\
\text { University }\end{array}$ \\
\hline $\begin{array}{l}\text { 20-29-year-olds } \\
\text { British nationality } \\
\text { Single without children } \\
\text { Single } \\
\text { Students } \\
\text { University }\end{array}$ & $\begin{array}{l}\text { Model C: } \\
\text { Egalitarian role } \\
\text { distribution }\end{array}$ & $\begin{array}{l}\text { Over 6o-year-olds } \\
\text { Italian nationality } \\
\text { Partnership with children } \\
\text { Widowed } \\
\text { Helping members of the } \\
\text { family } \\
\text { Lower school graduates }\end{array}$ \\
\hline
\end{tabular}

Table 2: Gender model preferences.

Model A, the traditional housewife model, is most favoured within the petty bourgeois milieu. Members of several milieus favour model B, a dual burden for the woman, at $20 \%$ each: the petty bourgeois, the underprivileged, the status-oriented and the meritocratic-oriented milieus. Model C, an egalitarian distribution of roles, is most favoured by members of the privileged liberal milieu. As stated above, model D, a dual burden for the man, finds the highest approval rating among members of the alternative milieu, and model E, the neo-traditional househusband model, among members of the hedonistic milieu. 


\section{Lived Gender Models}

The interviews clearly showed that all gender models are represented. Interviewees repeatedly stressed that women and men should be able to decide freely how to arrange their private lives. Some however also stated that a lack of childcare facilities, the low quality of these facilities and financial constraints, influenced the decision about who stays at home. Many female interviewees affirmed they enjoyed staying home as a mother. However, in individual cases, they then also elaborated on how much they missed external contact and intellectual activity. A further subject broached concerned the 'competition among mothers', for instance, when organising the perfect children's party becomes a yardstick for determining the 'quality' of mothers. It was frequently emphasised that bringing up children requires an "all-out commitment" and that men often do not consider themselves capable of meeting the demands of household and child education. They do not feel capable of performing educational tasks, it was said, above all with babies or toddlers, even if they are their own children. It is also evident that collectively organised households change once a child is born: as a rule it is the women who stay at home. Raising children is still not a matter of course for men. This confirms the results in the Favoured Gender Models Section presented earlier that role allocation based on partnership is closely linked to childlessness and parenthood. If, however, men do become active in the household or in bringing up slightly older children (mostly upwards of four years of age), then they, as well as their female partners, mentioned that this was often done with pleasure and enjoyment.

Another factor that contributes to a non-traditional distribution of housework and child care is professional independence, which facilitates the life-work balance because flexible working hours also enable fathers to spend more time looking after the children. The aspect of effectiveness is also mentioned: who can do what best and fastest? Ranked on a par with this are physical size, professional workload and the time factor. In terms of cooking, a lot also depends on what needs to be cooked and for whom, i.e. the degree of sociability. In one case, the woman cooks whenever there are English-speaking visitors so that she does not have to converse in English, which is left to the husband. Gender, culture, ethnic origin, linguistic competence and cooking all intersect in this instance: a clear example of how the concept of intersectionalty manifests itself in everyday life. Yet, Goffman-type front and back stages (Goffman 1969) also emerge in the interviews. For instance, when it is reported that in one relationship described as a partnership, the woman is responsible for doing the laundry in the basement and he for what happens "upstairs": she does the laundry and hangs it up; he irons and folds the clothes. Interestingly, this picture recurs in the spatial division of cleaning: "Sie putzt den hinteren Teil der Wohnung und ich den vorderen"29.

Concerning the question what prompted the decision to adopt a changed gender model, some of the interviewees cited their parents as a role model.

29 | Personal translation: "She cleans the rear side of the flat and I do the front". 
Others emphasised that they had conceived and applied their own gender model in pronounced contrast to what they had experienced at home with their parents. However, considerably more research is needed to gain a more precise understanding of these routes to change.

In the interviews, traditional gender models were often referred to as something completely normal and natural. The traditional aspect was generally never called in question. Also, it was often emphasised that there was even no need to discuss it. Here we can clearly observe both the non-explicitness of discourses of normality and the related 'discussion-free' adoption of role attributions. This could be seen as evidence for the assumption that in the hegemonic, discourse of normality only the non-normal is highlighted. For instance, the interviews often showed that the 'still' normal seems to be frequently sneered at by those who have freed themselves of it. Which, in turn, can provoke annoyance among the 'traditionalists' about the so-called arrogance of the 'others'.

\section{Knowledge of Laws and Provisions Relating to Male and Female Equality}

The over 6o-year-olds, in particular, are familiar with laws or Luxembourgish regulations relating to the equality of women and men. On the other hand, it is clearly the 16 to 20 year-olds who are aware of the Girls' and Boys' Day (GBD), an event meant to sensitise girls and boys to so-called atypical professions and which has been in existence in Luxembourg for girls since 2002 and for boys since 2005 . Whereas the Girl's Day is equally familiar to women and men, it is unequivocally clear that men are more likely to be familiar with legislation while women are more likely also to have heard about the Boy's Day. The laws and regulations are most familiar to Germans living in Luxembourg, while it is without doubt the GBD that is most widely known among Luxembourgers. On the whole, familiarity with laws, regulations and the GBD increases in proportion to the level of education.

A remarkable lack of awareness and knowledge of existing laws and regulations is evident from the interviews. More or less known are the following: pregnancy protection regulations, the "Wegweisungsgesetz" 30 , laws concerning equality of pay, marital status laws, divorce legislation, registered partnerships. Despite all ignorance, it is still frequently and emphatically claimed that legislation tends to favour women. The relevance of the laws and regulations for everyday life is negated in proportion to the level of ignorance. Interviewees are barely aware of the fact that they live in a society regulated by contracts. Laws and regulations are considered to be necessary only for special circumstances, for example, in the case of domestic violence. It is also stressed that one has to stand up personally for one's rights, even in the case of gender equality. The quota debate is often dismissed as nonsense.

30 | A law with provisions to combat domestic violence. It allows for an abusive member of a household to be expelled from that household by court order. 
Here we see an interesting cross-link to the discourse of competence, when it is stated that it is competence and not gender that matters. Gender disparities, it is argued, cannot be diminished by legislation, instead, it is a question of education, upbringing and a change of attitudes, and this takes time.

\section{Gender Category within the Polyphonic Choir of Intersectionality}

While, until the late 1990s, gender was considered to be the structural category within scientific feminist discourse, the present findings show that gender has lost some of its discriminatory power as a category of analysis. Having become just one aspect within the polyphonic choir of intersectionality, gender has been put into perspective. Individual sections emerge more or less strongly within the overall mesh of identities, depending upon the situation. At times it is age, sometimes professional standing, sometimes sexual orientation that is more significant and becomes the aspect that identifies the subject. According to the present findings therefore, gender assumes a rather inferior role in social interaction. When it comes to assumptions concerning femininity and masculinity, essentialist and constructivist notions of identities and genders are discursively tightly intertwined. This possibly points to an astonishing proximity and overlapping of these discourse figures, which are often treated as a dichotomy within the prevailing paradigm. Something similar obtains in the case of tolerance and discriminatory attitudes. In terms of preferences for gender models, hegemonic discourses of normality seem to have become as shaky as traditional notions of homosexuality and transsexuality, although they have not yet lost their effectiveness as an instrument of inclusion and exclusion and can still contribute to the marginalisation of minorities. Nevertheless - according to the findings - a lot has happened within Luxembourgish society in terms of increasing gender equality. Gender barriers have become more porous although the porosity does not yet seem to be in balance: it seems to be easier to transit from the so-called female side to the so-called male side than vice versa. And yet it is clearly evident that traditional gender representations have by no means completely lost their power, in particular in relation to parenthood. Parenthood still seems to impede the implementation of egalitarian partnership and professional practice. Women are still more likely than men to be willing to prioritise the family at the expense of their own professional activity. Actual structural changes such as rising employment rates for women, increasingly improved levels of education as well as a growing presence of women in politics and in the public eye (Allegrezza et al. 2007; Ministère de l'Egalité des Chances 2006; Ministère de l'Education Nationale et de la Formation Professionnelle 2007) have been proven to have had no direct influence on people's attitudes to the subject of gender. We can, therefore, speak of the persistence of 'resistant remnants' that, in the case of women, are likely to emerge in the areas of motherliness and responsibility for reconciling professional and family life and, in the case of men, in naturalistically based assumptions of essentially different genders as well as men's superior aptitude for professional life. 
Clearly, however, such gender-polarising attribution processes are undertaken by all genders in a gender-crossing manner. Notwithstanding these 'resistant remnants', (gender) identities are increasingly appearing as permanent performances within the intersectional canon. They form a space within which subjects can position themselves interactively and in which time and again the gender affiliations of the protagonists can play a role - and do so. The effectiveness of the categories is in a state of flux. The gender category has been set in motion: gender in motion.

\section{3 'Good’ Food. Oscillation between Political Concept and Individual Everyday Practice}

\section{Researching Identity-Relevant Food Standards and Practice}

The following identity construction case study is about normative ideas about 'good' food and how 'good' eating takes place in practice. The qualitatively as well as quantitatively oriented analysis body simultaneously covers institutional as well as individual dynamics: on the one hand, it is based on a group interview with experts as well as on political publications on the topic and, on the other hand, on a representative survey as well as qualitative interviews among Luxembourg's resident population.

This research topic offers the possibility of investigating the intermeshing of normative influences with largely routine and unquestioned discursive practices, by way of the subjects' banal and recurring need to eat. Because of human omnivorism ${ }^{31}$ (Fischler 1990), these discursive practices give rise to questions concerning the resource-driven food selection (what to eat?), its preparation and compilation (how to eat?) and communal eating with selected companions (with whom to eat?). The everyday, individual handling of these questions (Perceptas) permits an analytic look into their underlying and collectively available values, attitudes and standards (Conceptas) $^{32}$ - which in turn, enables one to draw conclusions about meaningful processes of "identity work", articulated through everyday actions (see Keupp et al. 2006). In this context, the concept of identity work is understood to be a form of autonomous self-construction as well as collective co-creation at the level of community and/or society. For it is precisely through bodily actions like eating that the individual consciously constructs itself as 'I' with idiosyncratic preferences and habits. At the same time, it is being both physiologically and symbolically constituted by the food ingested. It forms collective concepts of 'good' food by interpreting them, albeit individually, but without breaking out of the traditional framework. At the same time, the individual repertoire of actions, which includes

31 | The physiological fact that humans can eat nearly everything - however, within a framework of the culturally acceptable.

32| See Section 7.1. 
recipes, menu composition, taste preferences, table manners, meal creation, values and attitudes to food, food conversations etc. - is framed by the prevailing, collective (cultural, socio-economic and milieu-specific) attitudes, thought and knowledge bases (Bourdieu 2000; 1994; 1980). This suggests that everyday eating behaviour is closely interwoven with individual or collective identities; however, the relationship between them is neither unequivocal nor constant (Scholliers et al. 2001).

A certain lack of visibility, non-mentionability and intimacy are inherent in the apparently self-evident aspects of identity-relevant discursive practices. This has practical consequences for research, as interviewees in a qualitative partially-guided conversation are not easily able to verbalise those contexts and value concepts, which are of interest to us, due to the, for many, unusual subject area and the frequently unincisive self-reflection in relation to one's own eating habits. One consequence in terms of conducting the interviews was the need to steer the conversation towards the subject of collective identifications. Thus, the interviewees articulated the topics of food and identity in relation to ethnic, national or family affiliations through ostentatious or festive, often stereotyped, consumption of certain dishes or ingredients on specific occasions ${ }^{33}$. For instance, they made statements like: "We Portuguese eat a lot of fish" or "Quand on va boire un café dans un bistrot en Italie, dans n'importe quelle ville, on papote avec tout le monde sans problème"34. Such verbalisations at the collective level seem unproblematic, since they merely involve invoking existing collective attributions, the construction of which has already been completed and which are available as cultural identity choices. By contrast, it seems to be a far more complex task for interviewees to verbalise food and identity at an individual level. This is the area of self-construction, i.e. implicit, ongoing subjectivisation, which is often perceived to be problematic. It is characterised by potential selections between varying normative options (Corbeau/Poulain 2002) (35 $^{35}$ and accordingly generates insecurity on account of insufficient univocity. The latter can be experienced as a questioning of the self and therefore as a general feeling of vulnerability in the course of the autonomous modelling of identity in progress.

In order to lessen the effect of the described problem areas, research interest was directed towards an external and contrastive point of reference. This consisted of the interviewees' positioning their food-related discursive practices in relation

33 | The aim of this investigation was not to analyse the role of produits $d u$ terroir and regional cuisine in Luxembourgish identity constructions; this will be done elsewhere.

34 | Personal translation: "When you drink a coffee in a bar in Italy, no matter where, you can chat with anybody without a problem".

35 According to the food manufacturers and distributers, the variety of the possible menu plans is meant to simplify personal decisions by avoiding repetitive boredom; in fact, however, the orientation according to different standards, behind the various products, causes confusion. For instance, industrial, mass-produced ready-to-serve meals coexist alongside non genetically manipulated biological canned food. Both simplify food preparation, but they correspond to diametrically opposite production chains and consumption positionings. 
to a specific concept of 'good' food: a national action plan coordinated ${ }^{36}$ by four Luxembourgish ministries and launched in July 2007 under the programmatic title "Gesond iessen, méi bewegen"37. In the current context, this national action plan (hereinafter referred to as GIMB) is deemed to be the institutional attribution of an identity option, which is represented as being politically and socially desirable. This impression is reinforced when the substructure for the action plan - international comparisons of scientific findings as well as moral governing efforts in the field of public health (see below) - is taken into account. The converging as well as the divergent interactions between these morally loaded, collective attributions on the one hand and the ethically coined, individual appropriations on the other hand ${ }^{3}$ provide an insight into the subjects' dynamic identity work in the Luxembourgish context.

\section{Health Orientation at a Political Level}

\section{Political Concept of Action}

To find out which performative attribution, in the sense of a moral identification ideal, is being conveyed, via GIMB, one must begin by explaining the self-image of those responsible at a political level. The initial assumptions for political (prophylactic and, if necessary, corrective) intervention in the field of public health, concerning nutrition and exercise, are based on comparative scientific studies from the World Health Organisation (among others WHO 1999; WHO 2008) and the European Commission (among others CE 2007; CE 2005). In particular, recurring reference is made to the definition of obesity as an epidemic, which, it is assumed, accompanies increasing purchasing power and leads to a series of secondary illnesses ${ }^{39}$. At the national level, a study by the Luxembourgish

36 In detail, this concerns the relevant ministries in the areas of health, education, family and sport.

37 | Personal translation: "Eat healthily, get more exercise."

38 | We are following Foucault in his differentiation between morals and ethics. Morals stand for "a collection of values and action guidelines, which are foisted upon the individual and groups by various dictating instances - family, educational institutions, churches etc. It can be the case that these rules and values are emphatically formulated as part of a coherent doctrine and comprehensive system of instruction. But it can also be the case that they are transmitted in an unstructured manner and that, rather than forming a systematic whole, they constitute a complex interplay of mutually compensating, correcting, partially mutually exclusive elements, which therefore allow for excuses and compromises" (Foucault 1984a: 36). This "moral code" goes hand in hand with the ethical "way and manner in which one acts and behaves - how one constructs oneself as a moral subject, who acts in relation to the regulations constituting the code" (ibid., 36).

39 | Cardiovascular diseases, cancer, Type 2 diabetes, osteoporosis, etc. 
Ministry of Health and Ministry of Education ${ }^{40}$ produced similar results to those in neighbouring countries, which legitimised similar action strategies by the political decision makers within the scope of GIMB - from the integration into European and international networks up to exchanging information about the respective strategies.

In light of this background, any peculiarities of the Grand Duchy are not to be sought in the initial problem but rather in the political intervention's implementation ${ }^{41}$. Institutional courses of action at a national level are based on a panel of experts ${ }^{42}$, an inter-ministerial committee ${ }^{43}$ and on texts from the public domain ${ }^{44}$. The conceptual approach is based on the principles of Health in All Policies ${ }^{45}$, the policy of Santé $21^{46}$ and the European Charter on Counteracting Obesity 47 . Based on a "multi-factorial" ${ }^{8}$ understanding of health, these initiatives result in an interdisciplinary and intersectional political approach. Specifically the

40 | Ministère de l'Education Nationale et de la Formation Professionnelle/Ministère de la Santé/University of Karlsruhe 2006.

$\mathbf{4 1}$ | Even though the current two to four language communication system (German and French, at times extended to include Portuguese and English) represents a considerable additional effort, it also constitutes a considerable value-add by catering to different cultural patterns and points of references.

42 | Primarily, this involved discussions between medical practitioners of various disciplines about a scientific-technical consensus on nationally defined nutritional guidelines. In particular, the focus was on a sustainable and active implementation in the creation of a public health policy, i.e. of "uniting partners and enthusing them".

43 | This has a coordination and evaluation role for the projects submitted by partner institutions, which are to be run under the label and the logo of GIMB.

44 | In particular the policy signed on 05.07 .2006 by four ministries (health, education, sport and family) known as "Politique commune favorisant l'alimentation saine et l'activité physique", in the form of the "Programme national pour la promotion de l'alimentation saine et de l'activité physique "Gesond iessen méi bewegen'", but also the criteria to be met by submitted projects to obtain the right to use the GIMB label and logo.

45 | Flagship initiative of the Finnish Ministry for Social Matters and Health (in international political cooperation), during the Finnish EU presidency in 2006, for promoting "healthy decisions" and "health education" (Ståhl et al. 2006: 15).

46 | The World Health Organisation's framework policy concerning health in the European zone (51 nations).

47 | European ministerial conference, Istanbul, 15.-17.11.2006.

48 | The interview quotes from the section "Health Orientation at a Political Level" are taken from the expert discussion on 16.12.2008 with the responsible team in the Ministry of Health (which, as is not unusual in Luxembourg, was held in various languages, but has been reproduced in English for reasons of legibility), whereas the quotes from the section "Personal Responsibility in Everyday Nutritional Management" come from interviews with members of the resident population of Luxembourg. 
health ministry draws together thematically and temporally circumscribed "actions" or "projects" initiated by partner institutions like schools, Maisons Relais pour Enfants ${ }^{4}$, local authorities, but also by associations and the like, and implemented under the GIMB motto. In addition, the ministry provides these "actors in the field" with a platform for the exchange of experiences and networking, but without systematised feedback of the results of their initiatives. Much less is there any formal communication between the ministry and the population as a whole, except via school children. These are supposed to come into contact with state-funded educational materials ${ }^{50}$ distributed throughout all schools and to then sensitise their parents. This process - if it happens at all - is designed for the long term and geared towards social and cultural change. This "profound change of habits" is exactly what those responsible for GIMB are striving for, i.e., for "awareness creation that leads to mobilisation, interest and commitment". GIMB projects, therefore, are not about a "one-to-one implementation of the ministerial guidelines, but are based upon a creative interpretation of what is practically achievable".

\section{Information Campaign for the Resident Population}

So those responsible for GIMB see themselves primarily as impulse providers for a sustainable and long-term process, which they support from the top down through different institutions and would ultimately like to see embedded in society. As a counterpart to the core activity of the ministerial assignment of the GIMB logo and label for specific actions, a bilingual information pamphlet containing guidelines on health-promoting exercise and nutrition in daily life was distributed to the entire resident population.

The resident population's engagement with GIMB detected during our interviews shows that only the above-named public relations work has been perceived. The "green pamphlet" 51 - as the pamphlet "Freude am gesunden Essen. Spaß an der Bewegung/Le plaisir de bien manger et d'être actif!" 52 (2007 edition) was often called by those interviewed - is divided into a two-page introduction, nutritional recommendations, advice on physical exercise (one and a half pages) as well as an address list of central institutions (half a page). The main emphasis, at a total of seven pages, is on nutrition, which can presumably be traced back to the

49 | A form of day-care centres for children, founded as part of the grand-ducal Règlement of 20.07.2005.

50 | Various topical folders were developed in collaboration with the publisher aid (Bonn, Germany), which are designed to be attractive, practically oriented and playful. Teachers are free to use these in everyday school life at their own discretion.

$\mathbf{5 1}$ | The bright green colour chosen as a background for the entire pamphlet makes a statement because it connotes vegetables on the one hand (representing the aspect "gesond iessen", see also our interview analysis) and nature on the other (as backdrop for outdoor leisure activities as a young family related to the aspect of "méi bewegen").

52 | Personal translation: "Enjoying healthy food, enjoying exercise!". 
numerous options available in this area, in contrast to the catchy maxim "exercise at least 30 minutes a day" (page 9).

Notwithstanding the pamphlet's serious contextual foil - which points out the statistical correlation between poor nutrition and insufficient exercise with the diseases of civilisation, health insurance costs and death rates, making "urgent action necessary" (page 1) - the authors have endeavoured to keep the tone playfully positive and encouraging. The pamphlet's summery-fresh colours and amusing illustrations emphasise this additionally. On the whole, the recommendations are formulated in a positive manner, e.g., "consume milk and dairy products every day" (page 5), etc. Wherever it is not possible to rephrase the negative aspects of a message, an alternative is offered, e.g. "limit the consumption of fatty food. Use vegetable fats in preference to animal fats" (page 4). Thus rather than some foods being "forbidden", value is placed on variety and food intake based on the nutrition pyramid, i.e., based ultimately on the assumptions of dietetics ${ }^{53}$.

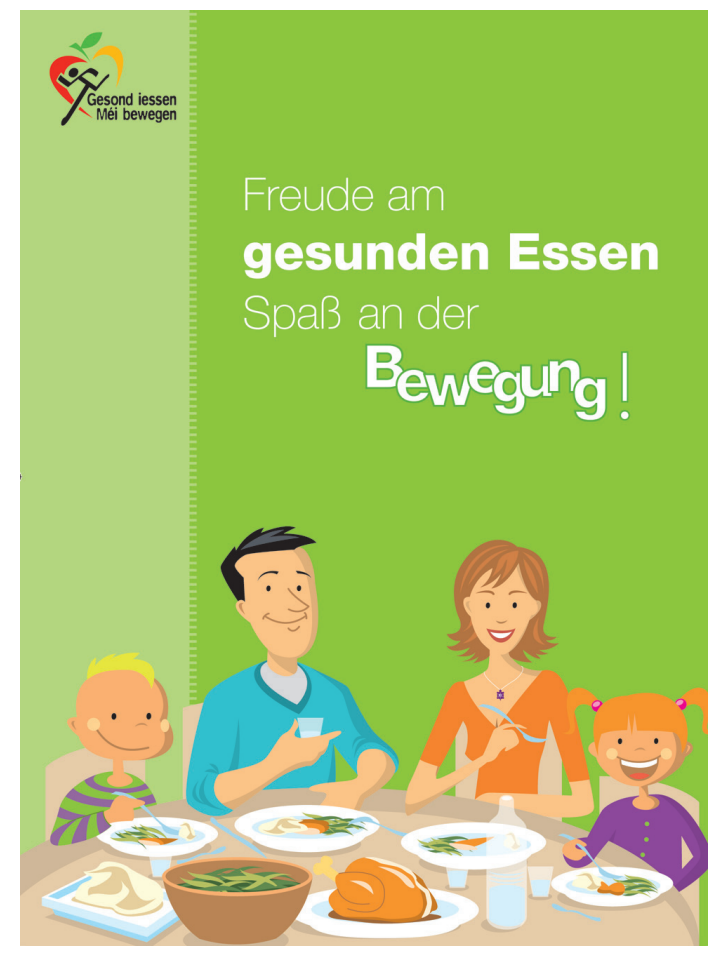

Figure 2: Cover page of the pamphlet "Freude am gesunden Essen. Spaß an der Bewegung!/Le plaisir de bien manger et d'être actif!" (2007 edition) (Enjoying healthy food, enjoying exercise).

53 Significantly, the Association Nationale des Diététicien(ne)s du Luxembourg is the only national level non-state partner organisation mentioned in the pamphlet. 
In the Health Minister's introduction to the pamphlet, the legitimacy of the euphemistically described effort, which the intended change of eating habits entails ("I wish you stamina"), is reinforced by greater self-esteem arising from "joy" and "feeling comfortable in your skin" among other things. For instance, "I wish you stamina" goes hand in hand with the "fun of discovering new eating and exercise habits and incorporating them into your daily life" (page 1). This distancecreating grammatical form conceals a judgement: a specific 'I' appears in a position of superiority, which provides benevolent advice to the readership. An inclusive formulation would have been more able to articulate solidarity as expressed, for instance, by the authors of the collaborating institutions: "Let's discover the benefit and fun together [...]; they are an important component of our well-being" (page 2). But even in this text passage, the 'bad' habits - which make action by the state necessary - are attributed to the readership constructed as an alterity: "By no means is it necessary to abstain completely from your favourite foods for good health". The apparent complicity at this point creates the impression, through the affectively felt experience of eating, that there is a natural relationship between what is unhealthy and what is preferred. The basic concept behind the pamphlet can ultimately be summed up in a result derived from "various studies" 54: "every fourth adolescent and every second adult suffers from obesity" (page 2). On the one hand, this statement refers to obesity in terms of an 'ailment'55, the existence or impact of which is not or is only to a small extent considered by those affected ${ }^{56}$. Thus the people we interviewed, for example, did not primarily refer to their body weight as a motivation for healthy eating. Rather, they raised the issue of an ethical endeavour to handle their own general health-capital responsibly - however, not in terms of preventing specific pathologies. From a formal point of view, the radical attribution of 'ailment' represents a break with the reformist-constructive change of habits, which the pamphlet endeavours to convey through the use of a respectful and considerate vocabulary. On the other hand, the statement cited above focuses on the individual and, in this regard, comes close to the everyday experience of eating. Our interviews confirm the feeling of the interviewees that for the most part, food choice and food preparation is an individual and complex decision, which concerns the person and his/her immediate environment (e.g. when he/she cooks for family, roommates, guests, etc.). According to the survey results, the demand for a well-balanced meal has a tendency to increase when children are present at the family dining table. The pamphlet acknowledges this circumstance in as much as the illustrations exclusively depict young families, which implicitly represent the

54 Remarkably, these scientific statements are translated in the French version of the pamphlet as "faits" (personal translation: "Facts") (p. 2).

55 | A more value-free description could have been "[...] overweight" (although this too smacks of a reference to a standardised ideal value).

56 | The HBSC studies on this topic carried out at an international and national level are only available in relation to adolescents. 
most important target group. In terms of content, the focus on the individual food components ${ }^{57}$ assumes an analytical knowledge of cooking ingredients, food and meal combinations - although the ministerial recommendations view themselves in general as more pragmatically oriented and provide specific guidance ${ }^{5}$. Thus, the recommendations can also appeal to other population groups, as will be shown on the following pages.

\section{Personal Responsibility in Everyday Eating Practice}

\section{Selective Internalisation of General Dietary Recommendations}

The authors of the institutional identity option GIMB consider 'good' food to be 'healthy' food, which is varied and balanced and the consumption of which should provide pleasure. The interviewees' understanding deviates partly from this health-oriented concept, due to the selective acceptance of different aspects of this approach while disregarding others, as well as extending the category of 'good' food by differently oriented, individual or intersubjective criteria.

Part of these relative divergences can be traced back to the level of familiarity with GIMB: $70 \%$ of the interviewees state that they have heard of GIMB. However less than half of these ( $43 \%$ ) have actively engaged with it (above all from the privileged liberal and the alternative milieus, i.e. mainly people with university degrees and a high income ( $€ 5,000-7,000)$, mostly with children). Apart from that, not much attention is paid to the nationwide ministerial information campaign: "I didn't give it much thought", "Also schon eng Kéier duerchgekuckt, jo mä net méi"59, "do war mol sou e Flyer" ${ }^{\circ}$ or "ech kennen nëmmen d'Iwwerschrëft" ${ }^{1}$.

Remarkably, the information provided by the interviewees about their daily and weekly menus indicates - at least at a discursive level - a selective internalisation of general dietary recommendations, even if these are not specifically associated with GIMB. This result is only partially associated with the socio-cultural milieus considered; in particular for the categories sweets and pastries, fruit and vegetables, as well as cereal products, there is a consensus in all milieus (no deviation from the average of greater or less than $5 \%$ ), and for alcoholic beverages and meat in nearly all milieus (one deviation of greater or less than $5 \%$ ). The food categories least influenced by socio-demographic variables ${ }^{62}$ - the consumption of which is thus the most stable for society as a whole - are milk and dairy products, cereal

$\mathbf{5 7}$ | Fruit and vegetables, fats, liquid, pastries, dairy products, salt and sugar.

$\mathbf{5 8}$ | For instance, the fact that one can estimate the approximate fat content of pastry by the "grease spots on the packaging" (p. 4).

59 | Personal translation: "Well, I have leafed through it once, yes, but not any more".

60 | Personal translation: "There was one of those flyers once".

61 | Personal translation: "I only know the title".

62 Age, gender, education, occupation, family situation and occupational state of the interviewees. 
products as well as fruit and vegetables ${ }^{63}$. Accordingly, $81 \%$ of the interviewees stated the following as the most widespread dietary ideal: "light and briefly cooked meals constitute good food".

\begin{tabular}{|c|c|c|c|}
\hline Food category & $\begin{array}{l}\text { Total per- } \\
\text { centage } \\
(\mathrm{a}+\mathrm{b})\end{array}$ & $\begin{array}{l}\text { Most frequent } \\
\text { answer (a) }\end{array}$ & $\begin{array}{l}\text { Second-most frequent } \\
\text { answer (b) }\end{array}$ \\
\hline \multicolumn{4}{|c|}{ Information on how often consumed per day } \\
\hline $\begin{array}{l}\text { Milk and dairy } \\
\text { products }\end{array}$ & $85 \%$ & $\begin{array}{l}\text { Two to three times per day } \\
(43 \%)\end{array}$ & Once per day (42 \%) \\
\hline Fruit and vegetables & $83 \%$ & $\begin{array}{l}\text { Two to three times per day } \\
(44 \%)\end{array}$ & Once per day (38 \%) \\
\hline Alcoholic beverages & $78 \%$ & Never $(43 \%)$ & Once per day $(35 \%)$ \\
\hline $\begin{array}{l}\text { Sausages and cold } \\
\text { cuts }\end{array}$ & $77 \%$ & Once per day (48\%) & Never $(29 \%)$ \\
\hline Salty snacks & $77 \%$ & Never $(52 \%)$ & Once per day $(25 \%)$ \\
\hline Sweets and pastries & $71 \%$ & Once per day (56\%) & $\begin{array}{l}\text { Less than once per } \\
\text { day }(15 \%)\end{array}$ \\
\hline Soft Drinks & $65 \%$ & Never (39\%) & Once per day $(26 \%)$ \\
\hline \multicolumn{4}{|c|}{ Information on how often consumed per week } \\
\hline Cereal products & $95 \%$ & $\begin{array}{l}\text { More than three times per } \\
\text { week }(78 \%)\end{array}$ & $\begin{array}{l}\text { Two to three times } \\
\text { per week (17\%) }\end{array}$ \\
\hline Meat & $90 \%$ & $\begin{array}{l}\text { More than three times per } \\
\text { week }(50 \%)\end{array}$ & $\begin{array}{l}\text { Two to three times } \\
\text { per week }(40 \%)\end{array}$ \\
\hline Fish & $87 \%$ & Once per week (57 \%) & $\begin{array}{l}\text { Two to three times } \\
\text { per week (30\%) }\end{array}$ \\
\hline Potatoes & $80 \%$ & $\begin{array}{l}\text { Two to three times per } \\
\text { week }(44 \%)\end{array}$ & $\begin{array}{l}\text { More than three times } \\
\text { per week }(36 \%)\end{array}$ \\
\hline
\end{tabular}

Table 3: The Luxembourg resident population's daily and weekly food consumption frequencies.

In response to the interview question about what is important in relation to nutrition, "balance" is stated as a central concern, and also the moderate consumption of any type of food. This also corresponds to a central concern that is communicated in the GIMB brochure (see above), and it is certainly the most innovative aspect of contemporary international dietary campaigns (Coveney 2006), because it approaches the interviewees' eating habits. They often stated that "more fruit and vegetables" is desirable; only now and then, however, was this mentioned in one breath with the "five a day" slogan. Finally, the interviewees stated that the diet should not be "too fatty" - but here, the health aspect overlaps with the powerful ideal of slimness. The more specific recommendations relating

63 | A more detailed depiction of the results is not possible here. 
to water and alcohol, pastries, dairy products, salt and sugar, on the other hand, are never or rarely mentioned spontaneously. To some extent, this bracketing out can be traced back to the extremely high everyday value of food, which entails a certain resistance to self-reflection.

\section{'Doing Identity' between Personal Responsibility, Potential to Take Action and Pragmatism}

This everyday experience concerning 'good' food comprises several identity-relevant dimensions, which extend beyond the boundaries of the technical preparation of meals (as conveyed by GIMB and other nutritional approaches). These can be collected into three discourse-practical strands of Doing Identity:

1) The most common discourse is that of personal responsibility, which can be divided into three variants (positive, flexible, negative) and fulfills different demands (subjectivation, responsibility for children and a consumption that is oriented on ethical ideals).

In the positive variant, the daily concern for 'good' food constitutes a challenging field of action, within which self-determined subjectivations can be tried out (through one's own cooking) and developed (by way of the resulting preferences). This is about "einfach ze probéieren" 64 and enjoying without feeling guilty ("ët soll schmaachen", "Schëllegkeet erof"65). "Aimer ce qu'on mange" ${ }^{66}$ is understood in the double sense of good taste and a positive fundamental attitude towards food, and the options available on the market are seen as an opportunity instead of being taken for granted ("mir kënnen eis kafen wat mir wëllen"67).

Ich bin grundsätzlich mit meiner Ernährungsweise im Alltag zufrieden. Ja. Die hängt ja von mir ab. Wenn ich was Falsches koche, dann kann ich nicht sagen, ich bin beim Kochen nicht zufrieden $^{68}$ (Male, 50 years old, Luxembourger, Junglinster).

Ech passen zimlech op datt et ë bëssen gesond ass, jo vill Uebst. Ech denke mer, et kann een jo awer vill maachen fir seng Gesondheet, dat kann een nët alles den Genen iwwerloossen, ech mengen et kann een och sälwer maachen ${ }^{69}$ (Female, 74 years old, Luxembourger, Dudelange).

64 | Personal translation: "Simply to try things out".

65 | Personal translation: "It has to taste good"; "without feeling guilty".

66 | Personal translation: "Love what you eat".

67 | Personal translation: "We can buy what we want".

68 | Personal translation: "I am basically happy with my daily eating habits. Yes. It depends on me, after all. If I cook something wrong, I can't say, I am not happy with the cooking".

69 | Personal translation: "I do take care that it is healthy, yes, plenty of fruit. I think that you can do a lot for your own health, you can't leave it all up to the genes, I mean, you can make a contribution of your own". 
Ech sin zefridden mat menger Ernährungsweis am Alldag, wëll ech éischtens mol doheem sälwer kachen, dat heescht ech sichen sälwer eraus wat ech iesse wëll. [...] Firdrun hun ech alles giess wat mir an d'Aën geflunn ass, ewourobber ech Loscht hat, an elo kucken ech vill méi drop wat ech genau iessen, zum Beispill méi Friichten, manner Schokela, nët zevill naschelen [...]. Am wichtegsten ass esou équilibréiert wéi méiglech, elo nët all Dag Nuddelen, mee esou vill wéi méiglech an verschidden ewéi méiglech an och... jo nët ze vill Naschereien dertëschent, dat heescht datt ech wirklech ee fixe Plang hunn ${ }^{70}$ (Female, 18 years old, Portuguese, Stadtbredimus).

However, more widely spread than such decidedly voluntaristic positions, we find flexible arrangements where individual deviations are tolerated if the overall balance seems subjectively adequate:

Ech denke mëttlerweil datt ech also net sou schlecht..., awer bon, 't sinn mol Saachen derbäi, déi net onbedéngt misste sinn. Mee bon, se sinn derbäi ${ }^{71}$ (Female, 27 years old, Luxembourger, Vianden).

By contrast, the negative variation of the discourse of personal responsibility is often associated with the argument of "lack of time" but also with culinary conservatism. However, this justification seems rather like a passive avoidance of the complexity of self-technologies in the culinary area $^{72}$, which means having to plan as well as to take ad hoc decisions, positioning oneself in a field of nearly boundless options, coming up with a wealth of ideas, technical skill and scheduling.

J'aimerais manger plus équilibré, plus... disons que je n'ai pas trop le temps donc euh... Et puis quand on mange au travail, on est toujours obligé de manger des choses qui vont vite euh... - Et vous pensez que vous pouvez un jour changer ça? - Non, je pense pas, mais pourquoi pas? Enfin, il faut se prendre peut-être le soir pour cuisiner quelque chose en avance et ramener au travail, euh je ne sais pas, j'ai pas encore trouvé la solution mais euh... - Qu'est-ce qui l'empêche en fait? - Ben le temps, le temps. C'est que quand on rentre du travail le soir, on est fatigué... Si, je pourrais, je pourrais... mais il y a des jours où ça va, mais c'est pas régulier, ça peut être un jour où je vais manger très bien, vraiment,

70 | Personal translation: "I am happy with my daily eating habits because, first of all, I cook for myself at home, which means that I choose what I want to eat. [...] I used to eat everything I saw, whatever I felt like and now I pay much more attention to what exactly I am eating. For example more fruit, less chocolate, not too much snacking [...] The most important thing is balance, so not pasta every day but as much as possible and as varied as possible and also... yes, not too many snacks in between, which means, that I really do have a definite concept". $\mathbf{7 1}$ | Personal translation: “These days I reckon I'm not doing all that badly... but, yes, sometimes there are things that are not absolutely necessary. But okay, they are there".

72 It remains to be clarified to what extent this concerns a self-assessment (lack of confidence) or being overwhelmed (lack of competence). 
salade, légumes, tout ça, poisson, et l'autre jour ça va être catastrophe ${ }^{73}$ (Female, 28 years old, French, Luxembourg City).

Ausgewogen na ja ... aber wir essen jeden Tag etwas anderes, unterschiedliche Speisen, aber ... Ich könnte vielleicht schon noch einiges ändern, aber es müsste alles so in der gleichen Geschmacksrichtung liegen, die wir gewohnt sind ${ }^{74}$ (Male, 38 years old, Portuguese, Consdorf).

One person, however, realises that the aforesaid lack of time has to do with a subjective priority allocation in other areas (in particular the professional field):

Ech sinn eigentlech net zefridden mat menger Ernährungsart a -weis, wëll ech u sech wéisst, wéi ee sech gesond ze ernähren hätt a probéiere menge Kanner dat ze vermëttelen, mä mech selwer awer meeschtens sou ënner Drock setzen, datt ech mech net drun halen ${ }^{75}$ (Female, 30 years old, Luxembourger, Dippach).

The ideal of responsible self-government - whether it is being implemented with a certain openness or with doubts and displeasure - gains significance if, in addition to the 'I', it also concerns one's own children. This feeding role seems to be internalised to the extent that it is still considered meaningful even in connection with adult offspring. The discourse of the necessary model role of the parents for their children includes in particular a normative upgrading of the category 'fruit and vegetables'.

Ech sinn zefridden mat der Art a Weis méi ech mech ernähren wëll dat bestëmmen ech jo selwer. An ech kucken wëll ech zwee Kanner hei am Stot hunn, bon deen een ass 18, dat

73 | Personal translation: “I would like to eat better-balanced meals, more... let's say that I don't have a lot of time, so, eh... And if one eats at work, one is forced to eat stuff which can be prepared quickly, eh... - And do you think that you will be able to change that one day? - No, I don't believe it, but then again, why not? Oh well, maybe one should take the time to cook something in advance in the evening and take it to work, eh ... I don't know, I haven't yet found the solution, but eh... - What stops you from doing it? - Oh, the time, the time. When you get back from the work in the evening, you are tired... However, I could, I would be able to... but there are also days when it would be possible but not regularly so, there can be a day where I eat very well, salad, vegetables, all that stuff, fish, and then there are other days where it is catastrophic".

74 | Personal translation: "Balanced ah, well... but we are eating something different every day, different meals but... I could probably still change a few things here or there but it would have to be along the same taste as what we are used to".

75 | Personal translation: "Actually I am not happy about my eating habits because, basically, I do know what I should be eating and I also try to get this across to my children, but I usually put myself under so much pressure that I don't keep it up". 
anert ass $24 .$. kucken ech awer datt bëssen Uebst a Geméis... a variabel, datt d'lessen net langweileg ass an datt se gär iessen, jo ${ }^{76}$ (Female, 53 years old, different nationality, Lenningen).

Ich finde Suppe sehr wichtig für die Ernährung. [...] Und es ist eine gute Art, die Kinder dazu zu bringen, Gemüse zu essen ${ }^{77}$ (Female, 47 years old, Portuguese, Putscheid).

The care for one's own children is, to some extent, associated with an ethical kind of consumerism. From a statistical point of view, this attitude is found among a section of the population that tends to include the older generation, with a slightly greater proportion of women, likely to be either not employed (housewife/househusband, retired) or to be self employed, with children and university degrees. Essentially this profile corresponds to that of those people, who know and have engaged with the GIMB, which means that GIMB is primarily reaching people, whose dietary habits are already orientated in the "desired" direction. In this context, action taken that is explicitly expressed as being of a responsible nature is either directed at the food itself (for instance, traceability or quality of the product) or at the production chain as a whole (for instance, seasonality, regionality, organic farming, fair trade or species-appropriate animal husbandry). Because efforts towards sustainability are motivated by a perceived added value for one's own health or also by the perceived affectivity during the production - i.e. by identity-relevant criteria - this attitude must be regarded as being ambivalent (Lamine 2008):

Ech ginn haaptsächlech an Bio Rayonen akafen. [...] Haaptsächlech Geméis muss wierklech... do muss nach eppes dra sinn. [...] Ech sinn iwwerzeegt, datt déi industriell Nahrungsmëttel, datt do, alles wat sou ouni Léift gemaach ass, datt do wierklech just nach minimal eppes Guddes fir eis dran ass ${ }^{78}$ (Female, 41 years old, Luxembourger, Bous).

2) Another thread within the discursive practice under review is that of the hypothetical potential to take action; in particular in the case of unexpected health problems or acute weight gain "wéisst een, wat een ze maachen hätt"79. However, as

76 | Personal translation: "I am happy with my eating because it is me who decides. And I see to it, because I have two children at home, well, one of them is 18 , the other one is $24 \ldots$ however, I see to it that a bit of fruit and vegetables... and alternately, that the food isn't boring and that they enjoy eating".

77 | Personal translation: "I consider soup to be very important for a healthy diet. [...] And it is a good way of getting children to eat vegetables".

78 | Personal translation: "I mainly buy organic food. [...] Primarily vegetables really have to... there still has to be something in it. [...] I am convinced that these industrial foodstuffs, that everything produced without love, only has a minimal amount of goodness left in it for us".

79 | Personal translation: "Would one know what to do". 
long as no significant changes are detectable, indulgence prevails with regard to the occasional 'lapse' - however these may be defined in daily life.

Fir déi Leit déi sech selwer iergendwéi iwwergewiichteg fannen oder déi selwer fannen datt se net gesond iessen ass dat vläicht ee flotten... een Input, sou ze soen an si gesinn, okay wann jiddereen dat mécht, dann kann ech och dozou bäidroen, mee ech perséinlech, also nee $^{80}$ (Male, 18 years old, Italian, Strassen).

This attitude can extend to a consciously stressed alternative attitude:

Da kuckt een dat [above-named pamphlet], et stellt een awer keng Gedanken drop, da leet een et rëm op d'Säit. Wëll mir beweegen eis net sou gär! ${ }^{81}$ (Female, 66 years old, Luxembourger, Ettelbruck).

A contradiction is often detectable between general and personal discourse levels. Initiatives like the GIMB (but also information about 'good' food in the media and in specialist literature) are considered to be generally desirable, however, the individual does not feel that it applies to them; thus for instance: "ech fannen et gutt datt de Ministère eppes mécht. Ob et eppes déngt, dat ass eng aner Fro". ${ }^{8}$ This is a typical everyday-cultural paradox, which is often circumnavigated by using humour. The ambivalence of the 'solution' is thereby defused for everyday use, but it is not nullified:

- Wie sind Sie auf das Programm Gesond iessen méi bewegen aufmerksam geworden? Durch die Medien. - Und was halten Sie davon? - In unserer Gemeinde gibt's auch so ein Slogan ein Mal pro Jahr. Da werden die Straßen hier für den Verkehr abgesperrt und ich glaube das geht in dieselbe Richtung ${ }^{83}$. - Haben denn diese ...? [Interrupts] - Die bewegen aber leider bei mir nicht sehr viel [laughs]! ${ }^{84}$ (Male, 37 years old, Luxembourger, Bertrange).

80 | Personal translation: "For people who themselves somehow think they are overweight or who feel that they aren't eating healthily, that might be a nice... input, so to speak, and they can see, okay if everybody is doing this, I can also contribute to it, but for me personally, not really".

$\mathbf{8 1}$ | Personal translation: "Then you look at it [the above-named pamphlet], but you don't waste a thought on it and then you put it away again. Because we don't really like exercising all that much!".

82 | Personal translation: "I think it is good that the ministry is doing something. Whether it will help, that is another question".

83 In the sense of a thematic action day, e.g. car-free Sunday.

84 | Personal translation: “- How did you become aware of the Gesond iessen méi bewegen campaign? - Through the media. - And what do you think of it? - Once a year there's a slogan like that in our local community as well. The streets are closed to traffic and I reckon that is 
3) Finally, one can detect pragmatism in the face of contradictory circulating standards against the background of the preceding discourse-practical threads. Effectively this pragmatism constitutes the most 'banal' and widespread pattern of behaviour in relation to the daily diet - precisely because of its inherent ambivalence, which does recognise the contradictions but is able to come to some arrangement with them. "Personal responsibility" and "hypothetical potential to take action" by contrast, function more as consciously adopted positions. The contradictory nature of the eating standards is perceived with differing degrees of intensity (from bewildering to indifferent to demanding). It can also be structured in a temporal manner - for instance, if the moral concepts of earlier food socialisation do not match those of the current habits. Furthermore, the ambivalence revealed by our research can have an ethical orientation, in particular at the structural development level of the food offer - for instance, if the industrialisation of food production gives rise to doubt about its quality. It also emerges depending upon the situation, mainly at the level of individual confrontation with specific constraints - for instance when there is a discrepancy between dietary recommendations and food supply. The following quote sums up these dimensions:

On n'arrive jamais à vraiment... Parce qu'en plus, la télé, les médecins, ils vous disent: “il faut manger comme ça", en plus maintenant la nourriture n'est plus aussi saine qu'avant alors... [...] On vous dit tout le temps, on vous dit plus quoi manger que dans le temps. Je veux dire, nos parents, on leur disait toujours: "mange, finis ton assiette, mange bien", et nous on nous dit: "attention, ne mange pas trop"! [...] II faut faire plus attention. [...] Y a beaucoup plus de choix et puis d'un autre côté, on vous dit: "attention, n'en fais pas trop", alors on est un peu frustré ${ }^{85}$ (Female, 28 years old, French, Luxembourg-city).

However, no matter how much cognitive effort is put into nutritional composition in everyday experience, it is compensated by a pragmatic focus on the communicative value and community formation through eating. Thus communal eating "am Familljekrees" 86 or "all zesummen" 87 is very important to many interviewees;

along the same lines. - Have these...? - [Interrupts] Unfortunately, they aren't achieving a lot in my case [laughs]!".

85 | Personal translation: "You never really manage... Because, in addition, television and doctors are telling you: 'You have to eat this and that'. Furthermore, food today is not as healthy as it used to be, therefore... You are constantly being told, they tell you much more than before, what you should be eating. What I mean to say is that our parents used to be told: 'Eat! Eat everything on your plate, eat well', and to us, they are saying: 'Be careful, don't eat too much!' [...] You have to be a lot more careful. [...] You have a far greater choice and on the other hand, you are told: 'Careful, don't overdo it', and then you get a bit frustrated".

86 | Personal translation: "With the family".

87 | Personal translation: "All together". 
accordingly, the statement "on working days, eating is a good chance for me to get together with others" was endorsed by $74 \%$ of those interviewed ${ }^{88}$ :

't ass einfach fir zesummen ze sinn an bëssen, jo, ze schwätzen. [...] Et schafft een, also déi eng ginn schaffen, déi aner ginn an d'Schoul, d.h. et ass ee bal ni zesummen a wéinstens ass een dann, wann een ësst, dann ass een zesummen. Et soll een och e bësse Kommunikatioun hunn ${ }^{89}$ (Male, 18 years old, Italian, Strassen).

\section{Oscillations of Identity}

The case example cited has highlighted convergences and discrepancies between moral attribution and ethical appropriation within the field of 'good' food, as an example of the crystallisation of identitary concepts at a political-institutional and everyday-cultural level. The process-oriented and creatively set up approach to health at the political level is practice-driven. While it focuses exclusively on food itself - its balanced composition and the resulting sensory wellbeing - it nevertheless deals with only the analytic-cognitive part in respect of the 'good' eating habits of the resident population. Therefore, it appeals in particular to those people who take a positive or flexible view of the challenge of personal responsibility and subjectivation in relation to eating and who possess the necessary capital to do so. In these cases, identity work, in the above-mentioned sense, in the field of nutrition becomes to some extent a matter of self-realisation - for instance, when a deliberately chosen, health-oriented dietary ideology (e.g., whole foods, organic or organic-dynamic production, regional products, vegetarianism, or similar) acts as a specific, distinctive identity symbol. By contrast, the majority of the interviewees have a pragmatic, less purist and less health-oriented attitude towards nutrition, which is lived out in a less object-centered and more person-centered manner. Here, the focus is on subjective experience - more spontaneous, less thought through and, from a health perspective, possibly short-sighted - as well as on the intersubjective and cultural dimensions of communitarisation (Reckinger 2008). The latter manifests itself in particular in terms of concern for the children and communicative solidarity between meaningful others, i.e. as affective and social identity work in a more comprehensive sense than a focus on health alone. It is precisely this pragmatic-hedonistic and person-focussed orientation at the

88 Primarily there are two statistically significant variables in terms of this attitude: age and employment. In particular those who are not yet or no longer working, as well as the unemployed, place a high value on this kind of everyday sociability - which confirms, once more, that the emotional availability is decisive for eating.

89 | Personal translation: "It's just for the sake of being together and, yeah, to talk. [...] You go to work, well, some go to work, others go to school, that means you are almost never together and at least you are together whenever you're eating. You have to have a bit of communication as well". 
individual and collective level, which is being disregarded within the political identity option in question ${ }^{\circ}$. Accordingly, a permanent oscillation can be discerned in the interaction between the attributions and appropriations considered, because the institutional government aspiration in the sense of Foucault (here: GIMB) and the everyday-cultural aspiration for self-government (here: the members of the resident population we interviewed) partially overlap, thus allowing the existence of a permanent and fundamentally ambivalent variation. The ethical appropriation of the 'good' food ideal can be in harmony with the moral, intentional and correcting logic of the political attributions (identitary adaptation), deviate from them (identitary opposition) or follow completely different patterns (identitary independence). It is precisely this dynamism that constitutes the significance of the selected case example in terms of governmentality ${ }^{91}$ research and for investigating identity-related construction processes.

\subsection{Cross-Border Workers as Familiar Strangers}

Given its development and significance for Luxembourg society, the cross-border worker phenomenon suggested itself as a further illustrative example of processes of identity formation. With a total of 147,400 men and women (2009) commuting daily from Saarland and Rhineland-Palatinate (Germany), from Lorraine (France) or Wallonia (Belgium) to Luxembourg to work, the Grand Duchy has the highest number of cross-border workers in the EU 27 (European Commission 2009: 18$20)^{92}$. Half of them are French, while Belgians and Germans each account for one quarter. Their total number has multiplied six-fold since the end of the $1980 \mathrm{~s}$ and in 1995 there were for the first time more cross-border workers than resident foreigners working in the Grand Duchy while in 2001 the number of cross-border workers was greater than that of employees holding Luxembourgish citizenship. Today (2009), Luxembourgers make up $29 \%$ of the workforce, resident foreigners $27 \%$ and cross-border workers $44 \%$. Aside from soft factors (adequate jobs, career

90 | However because the GIMB was designed as a long-term and social "process" and not as a "project" with immediate tangible effects (Wagener 2008: 25), this kind of synergy would not be impossible in future.

91 | Following Foucault (1993; 1984b; 1983; 1982b; 1978; see also Bröckling/Krasmann/ Lemke [2001] this neologism is made up of "gouverner" (to govern) and "mentalité" (mentality) and permits a simultaneous and relational reading in collective and individual forms of identity governance in the form of moral and political rationalities as well as of ethical and individual approaches to the self. Thus state control converges with control of the self. However, this convergence is fundamentally dynamic and vriable as demonstrated by the case example presented here.

92 | Only in Switzerland are there more cross-border workers from the neighbouring countries. 
paths etc.), the strong attraction of the Grand Duchy can be primarily traced back to an attractive net income and the range of jobs on offer. For in contrast to the neighbouring regions, even during the economic recession more jobs are created in Luxembourg than can be filled with resident manpower, as shall be explained later.

\section{Theoretical Approach to the Status of the Cross-border Workers}

In view of the exceptionally high quantitative importance of and dependence on manpower from the neighbouring regions in evidence since decades, the question arises which status is assigned to cross-border workers in Luxembourg, that of the stranger or that of the one who is familiar. This study therefore focuses primarily on the Luxembourg resident population's perceptions of the cross-border worker phenomenon which represent different forms of appropriation or construction of the latter. On a theoretical level, preoccupation with the strange first of all leads us to that direction of sociology which Stichweh calls the "classical sociology of the strange" (Stichweh 2005). This refers to Georg Simmel's essay "The Stranger" in which the author establishes a relationship between the stranger as a traveller and a given social community. He draws a distinction between the consequences for the absorbing community and their observation from the perspective of the stranger (Simmel 1908). These positionings are expanded by Robert Park in his concept of the marginal man who inhabits the borderline between two cultures and must develop resources in order to solve a cultural conflict (Park 1974). Finally, from an action-theoretical perspective, Alfred Schütz poses the question of the psychological processes that the stranger has to deal with once he enters a field of unfamiliar civilisation patterns (Schütz 1971). Just like Park, Schütz measures the status of the stranger by whether he/she manages to accept the rules prevailing in the absorbing community or whether, as a stranger, he/she ends up neither fully belonging to his/her old nor to the new environment. The common characteristic of these approaches lies in the fact that they both consider the stranger an 'intruder' into a given society which is described as a normatively integrated collective. This notion of homogeneous ingroups which are only barely accessible to outsiders presumably goes back to the experience of uni-directional and permanent migration in the 19th and 2oth centuries and can be best associated with the dichotomic figure of thought of familiar/strange. With respect to the cross-border worker phenomenon as a circulatory form of mobility, this would mean that the status question could be solved via norm-related affiliation. Therefore, cross-border workers could either be defined as familiar insiders - who have mastered the normative set of rules of Luxembourg society - or as alien outsiders.

However, with transnational lives becoming an evermore widespread phenomenon (Pries 2008; Kreutzer/Roth 2006) that also includes cross-border workers, the figure of thought based on norm-related affiliation has become too limiting. Rather, we need to question "um welche Modalitäten es sich eigentlich handelt, in 
denen jemand als Fremder erfahren werden kann"93 (Stichweh 2005: 141). From a transnational perspective, therefore, the question of the stranger or the alien can no longer point to national supercollectives and 'intruders' required to adopt given norms or standards, but needs to focus on the constructions of the strange and the familiar performed by resident nationals. For if the perspective of the normatively integrated societies is to be broken up and the strange is to assert itself as a theoretical category also in post-modern everyday life, one needs to inquire into the processes that construct social phenomena as alien and/or familiar. With respect to the crossborder workers, it is therefore, necessary to determine their status on the basis of the appropriations and perceptions of the Luxembourg residential population. Armin Nassehi's approach, which introduces the dichotomy of positive and negative appropriation (+/-) of social phenomena, provides some conceptual clues for addressing this task (Nassehi 1995). According to this approach the familiar - as the reverse of the strange - can carry a binary connotation: a positive and a negative one. This theoretical approach, which can be expressed in the thought model of familiar (+/-)/strange, makes forms of internal social differentiation tangible. On the other hand, the thought model retains the category of the strange, which absorbs certain social phenomena that resist positive or negative appropriation by the subjects and therefore remain beyond the limits of the familiar. With respect to the status of the cross-border worker phenomenon, this means that the crossborder worker can be identified as being familiar if the appropriations performed by the residential population are either positive or negative. He/she would need to be defined as a stranger if the respective appropriations have to be considered ambivalent, i.e. if the residential population adopts a positive as well as a negative attitude towards the cross-border worker phenomenon. Such appropriation processes of the strange/alien or familiar are practiced in all societies, since they depend on the identity-constituting differentiations that are performed in everyday life by inclusion (positive appropriation) and exclusion (negative appropriation). This refers to inclusive and exclusive practice strategies that, as forms of everydaydiscursive appropriation, construct collective identities through specific semantics. It is against this background that we will take a closer look at the appropriation processes of the resident population in relation to the cross-border worker phenomenon.

\section{Everyday-discursive Appropriations between 'Indispensability' and 'Threat'}

Owing to the development of the Luxembourg employment market outlined above, there has been a growing awareness of cross-border workers within the resident population. The interviewees are convinced that the cross-border worker

93 | Personal translation: "Which are the actual modalities, under which somebody can be experienced as a stranger". 
phenomenon has become a much more prominent theme in everyday discourses than was the case during the 1980s. This in particular is due to the fact that commuters have become more conspicuously present and that, as a consequence, matters such as job competition or language contact have become substantial issues. It is also remarked that cross-border workers increasingly serve as a projection surface for social discontent, or, as an interviewee puts it: "Et gëtt ee gesicht, dee schold ass"94. The following insights into appropriation strategies concerning the cross-border phenomenon touch on aspects of the economy and the labour market as well as language and culture in Luxembourg. In the surveys, positive and negative implications of cross-border worker employment were addressed in order to create links to the thought model described above.

First of all, we will attempt to identify which appropriations of the cross-border worker phenomenon relate to socio-economic factors. To ascertain this we asked whether cross-border workers were necessary for Luxembourg's economy, which was confirmed by $87 \%$ of the interviewees, clearly reflecting a positive-inclusive attitude towards the commuters. This is based on two inclusion strategies: on the one hand, it has to do with the usefulness of labour provided by cross-border workers which is brought up as an issue under the aspect of the insufficient resident manpower and the demand for specific qualifications that can only be partially met by Luxembourg's residents. This is a consequence of Luxembourg's rate of economic growth, which would not have been (and be) possible without the contribution of cross-border workers. For instance, already for several years about two thirds of new jobs created annually have been filled with cross-border workers, not only bringing the necessary manpower into the country, but also the required qualifications.

Dat fannen ech ganz richteg, well mir hu jo eendeiteg net genuch Leit, déi schaffe ginn; an menger Usiicht no, wa mir keng Grenzgänger hätten, hätte mir vill méi Problemer hei zu Lëtzebuerg. Da giff eis Economie och guer net fonctionnéieren; an vu que datt mir awer déi Grenzgänger hunn, hu mer eng Chance fir ze fonctionnéieren, respektiv, wat elo mat der Finanzkrise kënnt, weess ee jo awer net; also, mä et sinn och vill Lëtzebuerger, déi einfach... bon, et wäert sécher alt, gesot: ze liddereg si fir schaffen ze goen; respektiv, si hunn einfach näischt geléiert, dat heescht si hunn op der 9ième opgehal, an... 'Oh mir kréie jo eng Plaz'. Mee haut kriss Du keng Plaz méi ouni, a mëttlerweil hunn d'Grenzgänger zimlech vill Chancen, well si awer vill méi Ausbildung hunn, wéi esou munnechen Lëtzebuerger ${ }^{95}$ (Female, 18 years old, Luxembourger, Heinerscheid).

94 | Personal translation: "They are looking for somebody to take the blame".

95 | Personal translation: "I think this is perfectly fine because we clearly don't have enough people here who are working; in my opinion, if we had no cross-border workers, we'd have a lot more problems here in Luxembourg. The economy certainly wouldn't run properly; but because we have the cross-border workers, it does; but then again, we don't know what's going to happen after the financial crisis ...; well, there are also many Luxembourgers who ..., yes, 
The second inclusion strategy also aims at theindispensability of cross-borderworkers without however, any direct social valorisation. According to the interviewees, their indispensability is derived from work activities which Luxembourgers are reluctant to perform. They sum it up by saying that "Luxembourgers think such work is beneath them" or "don't want to get their hands dirty", which is why cross-border workers are employed for "the dirty work". It is also remarked that cross-border workers are especially indispensable for badly-paid jobs which Luxembourgers refuse to take on.

An et sinn der och vill, wou verschidde Lëtzebuerger sech ze gutt sinn, fir déi ze maachen. ... Also, di Drecksaarbechten. Wann dat net bei der Gemeng ass oder esou, da si vill Lëtzebuerger, déi soen: 'Oh nee dofir ginn ech awer net schaffen'. Also do kennen ech der awer och, déi dat gesot hunn. Oder: 'Fir déi Paie ginn ech net'96 (Female, 31 years old, Luxembourger, Rambrouch).

When the qualifications of cross-border workers and their labour for low-paid jobs are emphasised, the interviewees also see in this a competitive advantage over Luxembourgers. This means, in everyday discourse, exclusive strategies are also practiced which can be subsumed under the keyword of 'job competition'. For instance, one third ( $34 \%$ ) of the resident population are of the opinion that crossborder workers take away jobs from the Luxembourgers and in this context the latter activate various exclusion strategies. They argue with the growing number of jobless who should be employed instead of cross-border workers, as well as with the low wages of cross-border workers, which allegedly push the Luxembourgers with their salary expectations out of the job market. Reference is also made to the image of the cross-border workers as "motivated employees", which is described as being the decisive factor for many employers and as being to the detriment of the Luxembourgers. In addition, there are a number of references to the "cross-border workerisation" of enterprises, accompanied by calls for the introduction of "quotas for Luxembourgers". Resident foreigners in particular emphasise the competitive relationship with cross-border workers and deplore that these speak just as little Luxembourgish as themselves, but still get a far better access to the job market. Two main reasons for this is the specific structure of selection mechanisms in

I suppose one can say who are simply too lazy to work;... or they just never had any training, they left school after the 9th grade and..., 'Yeah, we'll get a job somehow'. But nowadays you can't get a job anymore without, and meanwhile, the cross-border workers have quite a lot of opportunities because they've had better training than many Luxembourgers".

96 | Personal translation: "There are also many Luxembourgers who think certain kinds work are beneath them... in other words the dirty work. If they can't work for the municipality... there are many Luxembourgers who say: 'Na, I wouldn't work for that kind of money'. Well, I know some people who've actually said that. Or: 'I'm not budging for that kind of dosh'”. 
Luxembourg's education system and the rising unemployment rates since 2001, which particularly affect foreigners, adolescents and women (Statec 2009: 108).

Sie könnten ja auch die Zahl der Grenzgänger irgendwie begrenzen, statt 130.000 hereinzulassen ..., wenn das so weitergeht und immer mehr Leute hereingelassen werden, dann sieht es in Luxemburg bald nicht mehr so gut aus, so ist die Lage. ... Ein Portugiese kann praktisch nicht mehr hierher kommen, wenn er kein Luxemburgisch kann, und die anderen können doch erst recht kein Luxemburgisch; warum sollen die also herkommen dürfen und wir nicht? ${ }^{97}$ (Male, 38 years old, Portuguese, Consdorf).

Already since the 1990 os one can identify also on a practical level an exclusion strategy which has led to a segmentation of the job market. This involves the tendency of employees with Luxembourgish citizenship to increasingly withdraw from the private sector in favour of jobs in the public and semi-public sector (see Statec 2009). These are not only attractive in terms of job protection and social security but they also offer a 'safeguard' against the competition of foreign manpower. This development, called "withdrawal strategy" by Fehlen and Pigeron-Piroth (2009) becomes possible due to a "national entrenchment capital", which includes, aside from Luxembourgish citizenship, the respective language skills, socio-cultural knowledge and social networks within the country, something that, as a rule, is only to a limited extent available to cross-border workers.

[Le secteur public] constitue une sorte de refuge, dans lequel les salariés luxembourgeois peuvent faire valoir leurs compétences particulières (notamment linguistiques) qui sont raréfiées sur le marché. Il se trouve ainsi à l'abri de la concurrence des travailleurs étrangers, de plus en plus nombreux et qualifiés ${ }^{98}$ (Fehlen/Pigeron-Piroth 2009: 11).

Next, we will examine the appropriations regarding the cross-border worker phenomenon in the socio-cultural context of Luxembourg's culture and language. For this, members of the resident population were asked whether they considered

97 | Personal translation: "They could also somehow limit the number of cross-border workers, instead of letting 130,000 of them in ... if this goes on and more and more people are allowed in, then soon it won't look that rosy in Luxembourg anymore, that's the situation.... A Portuguese practically can't come here anymore if he can't speak Luxembourgish and the others really don't know a word of Luxembourgish; why should they be allowed to come here then, and not us? The Germans can't speak Luxembourgish either and yet they come here and work for the municipalities. In these cases, I don't think that's right. Why should they be allowed to come here ...?".

98 | Personal translation: "[The public sector] constitues a refuge of sorts, where the Luxembourgish employees can exploit their particular (primarily linguistic) competences which have become rare on the market. It is thus protected from the competition of foreign workers who are becoming more and more numerous and qualified". 
cross-border workers an enrichment to Luxembourg's culture. More than half of the interviewees (55\%) said they did, although we have to assume that the social desirability effect influenced the responses to a certain degree. For the inclusion of cross-border workers in the sphere of the familiar, as expressed here, corresponds first of all to a public discourse ${ }^{99}$ which unfolded particularly in the context of the cross-border worker festival in 2008. For instance, a press release of the Ministry of Culture, Higher Education and Research reads as follows:

Unter dem Motto 'Zusammen arbeiten, zusammen feiern, zusammen leben' hat das Fest zum Ziel, über die Arbeitsbeziehungen hinaus und außerhalb der Bürozeiten, einen echten interkulturellen Dialog und einen gemeinschaftlichen Geist zwischen Grenzgängern und Anwohnern, sowie unter den Grenzbewohnern selbst zu fördern. Das Fest der Grenzgänger hofft so ebenfalls zur Entwicklung einer gemeinsamen regionalen Identität beizutragen. [...] Für Luxemburg als 'Land der 100 Nationalitäten' ist die Vielfalt kein leeres Wort, und das Fest der Grenzgänger ist dazu berufen, keine einmalige Initiative zu bleiben ${ }^{100}$ (Ministry for Culture, Higher Education and Research 2008: 1).

In contrast to this inclusive strategy of identity attribution, the interviews also brought negative appropriations of the cross-border worker phenomenon to light. In these instances, the familiar is constructed by identity-constitutive differentiations when cross-border workers are expected to adapt themselves to Luxembourg's culture and show greater interest in and respect for Luxembourgers.

Et ass och fir mech een wichtegen Aspekt datt Frontalieren, wann se an Lëtzebuerg kommen, datt se net nëmmen heihinner kommen fir ze schaffen, mä datt se sech wéinstens e bëssen fir eis Kultur souzesoen interesséieren an och vläicht iergendwéi een Austausch oder kommunizéieren mat den Lëtzebuerger. Et sinn wierklech vill Frontalieren, déi gesinn Lëtzebuerg nëmmen als Staat, wou een Suen verdéngt; d.h. si kommen heihinner, si schaffen dann ginn si nees zeréck an si interesséieren sech guer net. Dat fannen ech ëmmer e bëssen blöd. Leit, déi awer dann heihinner kommen an vläicht dann eben sech integréieren an eis Gesellschaft dat fannen ech dann besser an wann si dann och nach

99 | See also section 5.5.

$\mathbf{1 0 0} \mid$ Personal translation: "With the theme 'working together, celebrating together, living together' the festival aims at promoting - beyond work relations and office hours - a true intercultural dialogue and a spirit of community between cross-border workers and local residents, as well as among the cross-border workers themselves. The cross-border worker festival hereby hopes to also contribute to the development of a common regional identity. [...] For Luxembourg, as the 'country of 100 nationalities', diversity is not an empty phrase and the cross-border worker festival is predestined to become more than a mere one-off initiative". 
versichen e bëssen Lëtzebuergesch ze schwätzen an dann fannen ech dat och gutt ${ }^{101}$ (Male, 18 years old, Italian, Strassen).

As the quote suggests, there is also an exclusive appropriation practice with respect to the Luxembourgish language. This is exhibited in the opinion that cross-border workers are a threat to the Luxembourgish language $(57 \%)$ as well as in the statement that cross-border workers should be able to at least understand Luxembourgish $(86 \%)^{102}$. The interviewees report that they are not able to communicate in Luxemburgish in the public space, in particular in the retail and catering trade and the health sector ${ }^{103}$, and state that anyone working abroad should, as a matter of course, also speak the local language, by which, in this case, they exclusively mean Luxembourgish. While cross-border workers are not expected to have advanced language skills, say the interviewees, they should however display at least elementary linguistic competences which would also be sufficient to "show their goodwill”.

Ech fannen et ganz schlëmm, datt een am Cactus, op lëtzebuergesch keng Wirschtecher méi bestelle kann, well si een net verstinn. Also, ech fannen ee Minimum vu Sprooch missten si awer kënnen, well wa mir an d'Ausland ginn, do kënne mer och net soen 'Hei, mir si Lëtzebuerger, mir kommen, hei schwätzt emol lëtzebuergesch mat eis'104 (Female, 31 years old, Luxembourger, Rambrouch).

The differentiation made above between people who speak Luxembourgish and those who have no knowledge of the language, as well as the fact that interviewees were prepared to qualify the linguistic competences expected from cross-border workers reveal that the Luxembourgish language, in the context of the cross-border worker phenomenon, functions primarily as an identity marker (Lüdi 2008: 187,

101 | Personal translation: "This is also an important aspect for me, that the cross-border workers, when they come to Luxembourg, don't only come here for the work but that they also take at least a little interest in our culture, or that they maybe somehow mingle with Luxembourgers or communicate with them. There are really many cross-border workers who see Luxembourg as a state where they can earn money; that is, they come here, they work and then they go home again and have no interest whatsoever [in the country]. I always find that a bit stupid. But if people come here and then maybe integrate into our society, then that's a lot better. And if they even try to speak a little Luxembourgish, then that's good too".

102 | See also section 4.2.

103 | See also section 4.3.

104 | Personal translation: “I think it's absolutely disgraceful that one can't order sausages in Luxembourgish anymore at the Cactus [a Luxembourg supermarket chain] because they don't understand you there. Well, I think they should at least know the basics of the language; because if we go abroad, we can't very well go and say to someone 'We're Luxembourgers, here we are, talk to us in Luxembourgish'”. 
190) rather than as an effective means of communication. This is partially also reflected by the strategies of language usage employed by the interviewees, who, in terms of language contact with cross-border workers, can be subdivided into four different types:

- The confrontational ones strategically try to exclusively speak Luxembourgish with cross-border workers and will, for example, leave a store if someone tells them "En français, s'il vous plaît" or "Comment?"105.

- The constructive ones, on the other hand, concede that cross-border workers cannot learn Luxembourgish if the resident population actively speaks the languages of the cross-border workers. Therefore they act inclusively and even speak Luxembourgish in difficult conversational situations if they notice that shop assistants or waiters "are making an effort".

- The pragmatic ones remain exclusive in their approach and speak apriori French, because experience has taught them that they will achieve their communicative objective by using this lingua franca.

- Finally, there are the mediating ones who absorb linguistic information in the context of greeting, or in conversation with another customer/guest/patient, and then act in a strategically inclusive manner by linguistically adapting to the shop assistant/waiter/care assistant.

The overall analysis of the findings shows that the Luxembourg resident population practises positive-inclusive as well as negative-exclusive strategies in respect to the cross-border worker phenomenon. On the basis of the quantitative data, one can take the investigation a step further and ask which strategies are activated in which social field. This requires a comprehensive examination of socio-cultural and socioeconomic aspects, for which the positive and negative statements about the crossborder worker phenomenon need to be collated (table 4).

\begin{tabular}{|c|c|c|c|}
\hline \multicolumn{2}{|c|}{ Positive Appropriation (+) } & \multicolumn{2}{|c|}{ Negative Appropriation (-) } \\
\hline $\begin{array}{l}\text { Socio-cultural } \\
\text { field }\end{array}$ & $\begin{array}{c}\text { Socio-econon } \\
\text { field }\end{array}$ & $\begin{array}{l}\text { Socio-cultural } \\
\text { field }\end{array}$ & $\begin{array}{l}\text { Socio-economic } \\
\text { field }\end{array}$ \\
\hline $\begin{array}{l}\text { Cross-border work- } \\
\text { ers are an enrich- } \\
\text { ment for Luxem- } \\
\text { bourg culture. }\end{array}$ & $\begin{array}{l}\text { Cross-border work- } \\
\text { ers are needed for } \\
\text { the Luxembourg } \\
\text { economy. }\end{array}$ & $\begin{array}{l}\text { Cross-border work- } \\
\text { ers are a threat to } \\
\text { the Luxembourgish } \\
\text { language. }\end{array}$ & $\begin{array}{l}\text { Cross-border work- } \\
\text { ers take jobs away } \\
\text { from the Luxem- } \\
\text { bourgers. }\end{array}$ \\
\hline $55 \%$ (approval) & $87 \%$ (approval) & $57 \%$ (approval) & $34 \%$ (approval) \\
\hline
\end{tabular}

Table 4: Positive and negative appropriation strategies of the Luxembourg resident population.

105 | Personal translation: “In French, please” or "What?". 


\begin{tabular}{|c|c|c|c|c|c|}
\hline & \multicolumn{2}{|c|}{ Socio-cultural field } & \multicolumn{2}{|c|}{ Socio-economic field } & \\
\hline & $\begin{array}{l}\text { Cross-border } \\
\text { workers are a } \\
\text { threat to the } \\
\text { Luxembourgish } \\
\text { language. }\end{array}$ & $\begin{array}{l}\text { Cross-border } \\
\text { workers are an } \\
\text { enrichment for } \\
\text { Luxembourg } \\
\text { culture. }\end{array}$ & $\begin{array}{l}\text { Cross-border } \\
\text { workers take } \\
\text { jobs away from } \\
\text { Luxembourg- } \\
\text { ers. }\end{array}$ & $\begin{array}{l}\text { Cross-border } \\
\text { workers are } \\
\text { needed for the } \\
\text { Luxembourg } \\
\text { economy. }\end{array}$ & \\
\hline Approval in \% & $\begin{array}{l}\text { Negative } \\
\text { appropriation } \\
(-)\end{array}$ & $\begin{array}{l}\text { Positive } \\
\text { appropriation } \\
(+)\end{array}$ & $\begin{array}{l}\text { Negative } \\
\text { appropriation } \\
(-)\end{array}$ & $\begin{array}{l}\text { Positive } \\
\text { appropriation } \\
(+)\end{array}$ & $\begin{array}{l}\text { Appropria- } \\
\text { tion overall }\end{array}$ \\
\hline $\begin{array}{l}\text { Luxembourg resi- } \\
\text { dent population }\end{array}$ & 57 & 55 & 34 & 87 & I \\
\hline $\begin{array}{l}\text { Status of cross- } \\
\text { border workers }\end{array}$ & \multicolumn{2}{|l|}{ Strangers } & \multicolumn{2}{|l|}{ Familiar + } & $\begin{array}{l}\text { Familiar } \\
\text { strangers }\end{array}$ \\
\hline $\begin{array}{l}\text { Privileged con- } \\
\text { servative milieu }\end{array}$ & 37 & 62 & 15 & 93 & l \\
\hline $\begin{array}{l}\text { Status of cross- } \\
\text { border workers }\end{array}$ & \multicolumn{2}{|l|}{ Familiar + } & \multicolumn{2}{|l|}{ Familiar + } & Familiar + \\
\hline $\begin{array}{l}\text { Petty bourgeois } \\
\text { milieu }\end{array}$ & 64 & 48 & 38 & 87 & I \\
\hline $\begin{array}{l}\text { Status of cross- } \\
\text { border workers }\end{array}$ & \multicolumn{2}{|l|}{ Familiar - } & \multicolumn{2}{|l|}{ Familiar + } & Strangers \\
\hline $\begin{array}{l}\text { Tradition-oriented } \\
\text { milieu }\end{array}$ & 74 & 45 & 54 & 86 & I \\
\hline $\begin{array}{l}\text { Status of the cross- } \\
\text { border workers }\end{array}$ & \multicolumn{2}{|l|}{ Familiar - } & \multicolumn{2}{|l|}{ Strangers } & $\begin{array}{l}\text { Familiar } \\
\text { strangers }\end{array}$ \\
\hline $\begin{array}{l}\text { Underprivileged } \\
\text { milieu }\end{array}$ & 64 & 53 & 56 & 75 & I \\
\hline $\begin{array}{l}\text { Status of the cross- } \\
\text { border workers }\end{array}$ & \multicolumn{2}{|l|}{ Familiar - } & \multicolumn{2}{|l|}{ Familiar - } & Familiar - \\
\hline $\begin{array}{l}\text { Meritocratic- } \\
\text { oriented milieu }\end{array}$ & 59 & 58 & 30 & 91 & I \\
\hline $\begin{array}{l}\text { Status of the cross- } \\
\text { border workers }\end{array}$ & \multicolumn{2}{|l|}{ Strangers } & \multicolumn{2}{|l|}{ Familiar + } & $\begin{array}{l}\text { Familiar } \\
\text { strangers }\end{array}$ \\
\hline $\begin{array}{l}\text { Privileged liberal } \\
\text { milieu }\end{array}$ & 46 & 62 & 16 & 89 & l \\
\hline $\begin{array}{l}\text { Status of the cross- } \\
\text { border workers }\end{array}$ & \multicolumn{2}{|l|}{ Familiar + } & \multicolumn{2}{|l|}{ Familiar + } & Familiar + \\
\hline Hedonistic milieu & 59 & 50 & 49 & 82 & l \\
\hline $\begin{array}{l}\text { Status of the cross- } \\
\text { border workers }\end{array}$ & \multicolumn{2}{|l|}{ Strangers } & \multicolumn{2}{|l|}{ Familiar - } & $\begin{array}{l}\text { Familiar } \\
\text { strangers }\end{array}$ \\
\hline Alternative milieu & 45 & 68 & 28 & 88 & 1 \\
\hline $\begin{array}{l}\text { Status of the cross- } \\
\text { border workers }\end{array}$ & \multicolumn{2}{|l|}{ Familiar + } & \multicolumn{2}{|l|}{ Familiar + } & Familiar + \\
\hline $\begin{array}{l}\text { Status-oriented } \\
\text { milieu }\end{array}$ & 53 & 48 & 26 & 93 & l \\
\hline $\begin{array}{l}\text { Status of the cross- } \\
\text { border workers }\end{array}$ & \multicolumn{2}{|l|}{ Familiar - } & \multicolumn{2}{|l|}{ Familiar + } & Strangers \\
\hline
\end{tabular}

Table 5: Status of cross-border workers in socio-cultural milieus. 
As far as the positive-inclusive appropriation strategy is concerned, one can note that the Luxembourg resident population tends to apply it in particular in the socio-economic field, for instance in the case of the indispensability of crossborder workers for the national economic growth (87\%) compared to the cultural enrichment of Luxembourg (55\%). Negative-exclusive appropriation strategies, on the other hand, take effect particularly in the socio-cultural field, for instance in the answers to the question concerning the threat to the interviewees' own language posed by cross-border workers (57\%) compared to job competition (34\%). However, this overview merely provides initial indications concerning the applied appropriations by social sectors and allows no statements about possible ambivalent appropriation strategies or about the status of the cross-border workers in socio-cultural milieus.

\section{On the Status of the Cross-border Workers in Socio-cultural Milieus}

Following on from the figure of thought outlined above of familiar (+/-)/stranger, the table 5 presents a systematised representation of the status of cross-border workers, based on the appropriation strategies of the Luxembourg resident population and on socio-cultural milieus. The observations are based on quantitative survey results and point to three essential types of status of cross-border workers in Luxembourg.

Cross-border workers as familiar individuals: The appropriation of the cross-border workers as familiar individuals is based on an unequivocally positive or negative construction of the phenomenon. In the case of cross-border workers being appropriated as negative familiar individuals - as they are in the underprivileged milieu - we tend to find mostly negative and exclusive appropriation strategies in both socio-cultural and socio-economic fields. In the latter these strategies are reflected by an emphasis on job market competition and the downplaying of the need for cross-border workers. With respect to the appropriation of cross-border workers as positive familiar individuals - predominant in the privileged conservative, privileged liberal and alternative milieus - positive and inclusive strategies prevail in the examined fields, expressed in the emphasis on the positive implications of cross-border worker employment and in the relativisation of the negative ones.

Cross-border workers as strangers: The appropriation of cross-border workers as strangers is based on an ambivalent construction of the phenomenon. This means that the interviewees applied positive as well as negative appropriation strategies in respect of the cross-border worker phenomenon. This form of appropriation is a feature of the petty bourgeois and status-oriented milieus which, on the sociocultural level, tend to display an exclusive attitude towards the cross-border worker phenomenon and, on the socio-economical level, an inclusive one. The factor of cultural enrichment is qualified in favour of a supposed linguistic threat by cross-border workers, which is particularly marked in the petty bourgeois milieu. Nevertheless, the need for cross-border workers is confirmed, and the alleged job 
market competition is seen as a relatively insignificant issue, particularly in the status-oriented milieu.

Cross-border workers as familiar strangers: The appropriation of cross-border workers as familiar strangers reflects a circumstance not foreseen by Nassehi, in the sense that in the social fields under review the cross-border worker is constructed in an ambivalent as well as in an unambiguous manner. This status is reflected in the appropriations of the Luxembourg resident population as a whole and the members of the hedonistic milieu in particular, who, from the sociocultural aspect, construct the cross-border worker phenomenon both positively and negatively. An illustration of this is the simultaneous assumption that crossborder workers provide cultural enrichment on the one hand and present a threat to the local language on the other. However, when it comes to their constructions in the socio-economic field, the groups mentioned above show marked differences: while the Luxembourg resident population in general stresses the indispensability of cross-border workers for the economy in an inclusive manner, the hedonists emphasise the job competition aspect, thereby assuming a rather exclusive stance. The status of cross-border workers as familiar strangers is also evident in the appropriation strategies of the tradition-oriented milieu. Here, however, we find an ambivalent construction on the socio-economic level with an emphasis on job market competition and the concurrently expressed need for cross-border workers, contrasting with a predominantly negative and exclusive strategy on the sociocultural level.

\section{On the Figure of the (Familiar) Stranger}

The analysis carried out here shows that the applied inclusion and exclusion strategies of the Luxembourg resident population represent different appropriation forms in respect of the cross-border worker phenomenon. In the socio-economic field, the predominant strategy tends to be the inclusion of cross-border workers by emphasising their economic indispensability. On the socio-cultural level, however, there is a marked tendency towards exclusion strategies based primarily on the perceived threat to the Luxembourgish language. These appropriation processes, which vary by socio-cultural milieus, were further examined for coherence, as a result of which partly contradictory constructions were revealed. These differ depending on the examined socio-cultural milieu and point to a largely ambivalent status of cross-border workers in Luxembourg, which has been represented by the figures of the stranger and the familiar stranger.

In view of the introductory remarks, these findings may at first seem to present an identitary dilemma. However, by interpreting them a potential logic in the strategic interplay of everyday-cultural inclusions and exclusions can be brought to light. For while, during the second half of the 2oth century, the presence of immigrants and cross-border workers "in den Köpfen zu einer Selbstverständlichkeit 
wurde"106 (Fehlen 2008: 82) due to local enterprises' demand for them, and xenophobic discourses thus barely evolved in Luxembourg, protectionist strategies against competition by foreign manpower have established themselves particularly since the periods of economic downturn in the new millennium. In the research findings these are reflected not so much by an open and consistent rejection of cross-border workers in the sense of the negative familiar but are conceded, for the reasons mentioned above, their economic indispensability. However, from the point of view of many Luxembourgers, this ends at the threshold to the public and semi-public sector, something which is regulated by the already mentioned entrenchment competence. Against this background, the logic of the strategic interplay of socio-economically motivated inclusion strategies on the one hand, and socio-culturally motivated exclusion strategies on the other, which aims at securing growth and prosperity at home and at protecting the job market, becomes clear. According to the findings, cross-border workers are considered important for the economy by the resident population, however, if they knew Luxembourgish, they might gain broad access to those sectors currently 'protected' from competition by 'foreign labour'. The socio-cultural argument of the linguistic threat - in particular in the tradition-oriented, underprivileged and petty bourgeois milieus - is applied in an exclusive manner in order to secure the competitive advantage over crossborder workers in the socio-economic field.

Therefore, appropriation processes concerning the cross-border worker phenomenon that at first glance may seem contradictory can indeed follow an 'everyday logic' that submits to the desire for security by imagining a community by demarcation. This suggests a further investigation of everyday-cultural appropriations of the cross-border worker phenomenon, which cannot be categorised along the lines of familiar or stranger, in terms of their nature as intermediate categories. This means explicitly focusing on the appropriations of the resident population with their inherent contradictions and thereby reconstructing the cross-border worker as an ambivalent yet independent category. At a conceptual level this implies a broadening of Nassehi's approach by the figure of thought of the familiar stranger [familiar (+/-)/ stranger]; at the empirical level, the task involves further clarifying the positions of the subjects between inclusive and exclusive appropriation processes and thereby elucidating the ambivalent logic of everyday culture.

\subsection{Conclusions: Identities and Ambivalences of Everyday Cultures}

In the presentchapter we investigated examples of different areas of everyday cultures and showed the (political) attributions and (individual as well as milieu-specific) appropriations in respect to identity-constitutive forms of action in circulation. It 
involved issues of gender-related performances and gender experiences, of attitudes concerning food and of the perception of cross-border workers in Luxembourg. In addition to their everyday relevance and identity-constitutive potential, it was possible to establish a further common characteristic of these topics: a distinctive ambivalence. This was clearly evident in the social practice under examination, where the binarities male/female, good/bad and familiar/strange are broken up in a productive and partly arbitrary manner, revealing different patterns of 'everyday logic'.

A remarkable result in the area of gender is the fact that the interviewees showed a tendency to embrace the ideal of sexual equality in their actions while at the same time still remaining mentally rooted in their traditional patterns. Conversely, they advocated gender equality while acting, for instance in the case of parenthood, according to traditional patterns.

This contradiction is also reflected in attitudes concerning food: findings on forms of attribution show that 'good' food tends to be treated in an object-centered manner (for instance in the form of nutritional guidelines), while, in terms of appropriation, there is a tendency to experience it in a person-centered way (for instance in the form of subjectification and communitisation). Here we see forms of practice that simultaneously integrate the attributed identification characteristics in a selective, context-related and constantly varying manner (e.g. in the form of adaptation, opposition or autonomy concerning nutritional guidelines).

Finally, while conceding that cross-border workers are important for Luxembourg's economy, interviewees critisise their Luxembourgish language competence, which is perceived as inadequate in everyday situations. At the same time, more importance seems to be attached to an appreciation of what is regarded as one's 'own' - to be performed by linguistic means - rather than to linguistic competence itself, in particular when it comes to those areas of the job market that are largely dominated and 'protected' by Luxembourgers and that very often can only be accessed by those who have a command of Luxembourgish.

In the case examples of everyday cultures examined here, we can identify discursive practices which pragmatically transcend a binary 'either-or logic' and follow a flexible 'as-well-as logic' - for instance, when, in the experience of gender, essentialisms as well as constructivisms are practised in parallel, when contradictory standards and habits of 'healthy' as well as 'indulgence' food mutually penetrate each other, or when cross-border workers are perceived both positively as well as negatively - and thus as 'familiar strangers'. In the context of our Luxembourg investigation, the various latent forms of 'everyday logic', by which dynamic identity constructions can be identified, therefore appear to be to a large degree pragmatic and self-related: a self-concept of the subjects, which experiences gender as only one aspect of everyday practice among many others and, depending on the context, argues either naturalistically or culturally; which favours pragmatic-hedonistic food habits in everyday life, or a self-image which gives in to the desire for that which is considered own's 'own' by ambivalent constructions of the 'strange'. 
In view of the above, it should be noted that this chapter deals primarily with appropriated identities and examines, in addition, to what extent attributed identities are (not) adopted, in the course of which strategies of adaptation, opposition and autonomy are activated in regard to models for identification. Therefore, identities are neither predetermined nor unalterable, but can only be traced as a snapshot and in a specific context of everyday practice.

\subsection{References}

\section{Primary Sources}

Ministère de la Santé/Ministère de l'Education Nationale et de la Formation Professionnelle/Ministère de la Famille et de l'Intégration/Département Ministériel des Sports. 2007. Freude am gesunden Essen Spaß an der Bewegung!/Le plaisir de bien manger et d'être actif! Luxembourg.

\section{Secondary Sources}

Allegrezza, Serge, Armande Frising, Antoine Haag, Jean Langers, Liliane Reichmann and Marco Schockmel. 2007. Egalité Hommes-Femmes. Mythe ou Réalité? Cahier Economique. No 105 du Statec, Luxembourg.

Antoni-Komar, Irene, Reinhard Pfriem Thorsten Raabe and AchimSpiller, ed. 2008. Ernährung, Kultur, Lebensqualität. Wege regionaler Nachhaltigkeit. Marburg: Metropolis.

Austin, John. 1962. How To Do Things with Words. Oxford: University Press.

Baltes-Löhr, Christel. 2006. Migration und Identität. Portugiesische Frauen in Luxemburg. Frankfurt/M./London: IKO-Verlag für Interkulturelle Kommunikation.

Baltes-Löhr, Christel. 2009. Umgang mit Differenzen. In Maison Relais pour Enfants. Le Manuel - Das Handbuch, ed. Manuel Achten, Christel Baltes-Löhr et al., 88-117. Luxembourg: Edition le Phare.

Barlösius, Eva. 2008. Weibliches und männliches rund ums Essen. In Kulinaristik. Forschung, Lehre, Praxis, ed. Alois Wierlacher and Regina Bendix, 35-44. Berlin: Lit.

Bhabha, Homi K. 2000. Die Verortung der Kultur. Stauffenburg Verlag: Tübingen.

Bolten, Jürgen. 2007. Einführung in die Interkulturelle Wirtschaftskommunikation. Stuttgart: UTB.

Bonz, Jochen and Karen Struve. Homi K. Bhabha: Auf der Innenseite kultureller Differenz: "in the middle of differences". In Kultur. Theorien der Gegenwart, ed. Stephan Moebius and Dirk Quadflieg, 140-153. Wiesbaden: VS-Verlag.

Bourdieu, Pierre. 2000 [1972]. Esquisse d'une théorie de la pratique. Précédé de trois études d'ethnologie kabyle. Paris: Le Seuil. 
Bourdieu, Pierre. 1994. Raisons pratiques. Sur la théorie de l'action. Paris: Le Seuil. Bourdieu, Pierre. 1980. Le sens pratique. Paris: Editions de Minuit.

Breinig, Helmbrecht and Klaus Lösch. 2006. Transdifference. Journal for the Study of British Culture 13/2: 105-122.

Bröckling, Ulrich, Susanne Krasmann and Thomas Lemke, ed. 2000. Gouvernementalität der Gegenwart. Studien zur Ökonomisierung des Sozialen. Frankfurt/M.: Suhrkamp.

Brunner, Karl Michael, Sonja Geyer, Marie Jelenko, Walpurga Weiss and Florentina Astleithner. 2007. Ernährungsalltag im Wandel. Chancen für Nachhaltigkeit. Vienna, New York: Springer.

Brunnett, Regina. 2009. Die Hegemonie symbolischer Gesundheit. Eine Studie zum Mehrwert von Gesundheit im Postfordismus. Bielefeld: transcript.

Butler, Judith. 1993. Für ein sorgfältiges Lesen. In Der Streit um Differenz, ed. Seyla Benhabib et al., 123-132. Frankfurt/Main: Fischer.

Chambers, Iain. 1996. Migration, Kultur, Identität. Tübingen: Stauffenburg.

Commission des Communautés Européennes (CE). 30 mai 2007. Livre blanc. Une stratégie européenne pour les problèmes de santé liés à la nutrition, la surcharge pondérale et l'obésit. Bruxelles: COM (2007) 279 final, non publié au Journal Officiel, http://europa.eu/legislation_summaries/public_health/health_determinants_lifestyle/c11542c_fr.htm.

Commission des Communautés Européennes (CE). 8 décembre 2005. Livre vert. Promouvoir une alimentation saine et l'activité physique. Une dimension européenne pour la prévention des surcharges pondérales, de l'obésité et des maladies chroniques. Bruxelles: COM (2005) 637 final, non publié au Journal Officiel, http://europa.eu/legislation_summaries/public_health/health_deter minants_lifestyle/c11542b_fr.htm.

Corbeau, Jean-Pierre and Jean-Pierre Poulain. 2002. Penser l'alimentation. Entre imaginaire et rationalité. Paris: Private.

Coveney, John. 2006 [2000]. Food, Morals and Meaning. The Pleasure and Anxiety of Eating. London: Routledge.

Csergo, Julia. 2009. Trop gros? L'obésité et ses représentations. Paris: Autrement.

Fischler, Claude. 1990. L'homnivore. Le goût, la cuisine et le corps. Paris: Poches Odile Jacob.

Deleuze, Gilles. 1968. Différence et Répétition. Paris: PUF.

Derrida, Jacques. 1968. La différance. Bulletin de la Société Française de Philosophie 62.3. Paris: 73-120.

European Commission. 2009. Scientific Report of the Mobility of Cross-Border Workers within the EU-27/EEA/EFTA Countries. (Directorate General for Employment, Social Affaires and Equal Opportunities), Luxembourg.

Fehlen, Fernand. 2008. Streit um den roten Löwen. Diskurse über das nationale Selbstbild Luxemburgs im Spannungsfeld von Modernisierung und Rückwärtsgewandtheit. In Periphere Zentren oder zentrale Peripherien? Kulturen 
und Regionen Europas zwischen Globalisierung und Regionalität, ed. Wilhelm Amann, Georg Mein et al., 61-87. Heidelberg: Synchron Verlag.

Fehlen, Fernand and Isabelle Pigeron-Piroth. 2009. Mondialisation du travail et pluralité des marchés du travail: L'exemple du Luxembourg. Discussion contribution of the 12e Journées de Sociologie du Travail, 25 and 26 June 2009, GREE, Université de Nancy. (http://gree.univ-nancy2.fr/digitalAssets/53345JIST_Fehlen_Pigeron.pdf).

Foucault, Michel. 1993. About the Beginnings of the Hermeneutics of the Self. Two Lectures at Dartmouth. Political Theory, $n^{\circ}$ 21/2: 198-227.

Foucault, Michel. 1984. Histoire de la sexualité, Tome 2: L'usage des plaisirs. Paris: Gallimard.

Foucault, Michel. 1984. L'éthique du souci de soi comme pratique de la liberté. In Michel Foucault. 1994. Dits et écrits. Tome 4: 1980-1988. Paris: Gallimard, pp. 708-729.

Foucault, Michel. 1983. On the Genealogy of Ethics. An Overview of Work in Progress. In The Essential Foucault. Selections from the Essential Works of Foucault 1954-1984, ed. Paul Rabinow and Nicolas Rose (2003 [1994]). New York \& London: The New Press, pp. 102-125.

Foucault, Michel. 1982a. The Subject and Power. In The Essential Foucault. Selections from the Essential Works of Foucault 1954-1984, ed. Paul Rabinow and Nicolas Rose (2003 [1994]). New York \& London: The New Press, pp. 126-144.

Foucault, Michel. 1982. Technologies of the Self. In The Essential Foucault. Selections from the Essential Works of Foucault 1954-1984, ed. Paul Rabinow and Nicolas Rose (2003 [1994]). New York \& London: The New Press, pp. 145-169.

Foucault, Michel. 1978. La gouvernementalité. Séminaire au Collège de France en

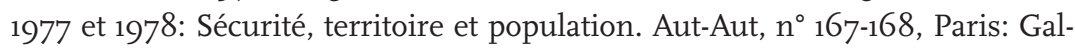
limard: 12-29.

Foucault, Michel. 1969. L'archéologie du savoir. Paris: Gallimard.

Goffman, Erving. 1969. Wir alle spielen Theater. Munich: Piper.

Gregory, Derek. 1997. Lacan and Geography. The Production of Space Revisted. In Space and social theory. Interpreting modernity and postmodernity, ed. Georges Benko and Ulf Strohmayer, 203-234. Oxford: Blackwell Publishers.

Hillmann, Karl-Heinz. 2007. Wörterbuch der Soziologie. Stuttgart: Alfred Kröner. Hörning, Karl H. and Julia Reuter. 2004. Doing Culture. Kultur als Praxis. In: Doing Culture. Neue Positionen zum Verhältnis von Kultur und sozialer Praxis, ed. Karl Hörning and Julia Reuter, 9-15. Bielefeld: transcript.

Hirschauer, Stefan. 2001. Das Vergessen des Geschlechts. Zur Praxeologie einer Kategorie sozialer Ordnung. In Geschlechtersoziologie. Ed. Bettina Heinz, 208-235. Westdeutscher Verlag: Opladen. Sonderheft der Kölner Zeitschrift für Soziologie und Sozialpsychologie.

Jakobson, Roman. 1971. Signe zéro. In Selected Writtings, II: Word and Language, ed. Roman Jakobson, 211-222. Den Haag: Parin. 
Klinger, Cornelia and Gudrun Axeli-Knapp. 2005. Achsen der Ungleichheit - Achsen der Differenz - Verhältnisbestimmung von Klasse, Geschlecht, "Rasse”/ Ethnizität. Transit 5/2005.

Kreutzer, Florian and Silke Roth. 2006. Transnationale Karrieren. Biographien, Lebensführung und Mobilität. Wiesbaden: VS Verlag.

Kumoll, Karsten. 2006. Clifford Geertz: Die Ambivalenz kultureller Formen. In Kultur. Theorien der Gegenwart, ed. Stephan Moebius and Dirk Quadflieg, 8190. Wiesbaden: VS-Verlag.

Lamine, Claire. 2008. Les intermittents du bio. Pour une sociologie pragmatique des choix alimentaires émergents. Paris: Editions de la Maison des Sciences de l'Homme \& Editions Quae.

Lüdi, Georges. 2008. Der Schweizer Sprachencocktail neu gemixt. Sprache als Brücke und Barriere. In Die neue Zuwanderung. Die Schweiz zwischen BrainGain und Überfremdungsangst, ed. Daniel Jentsch-Müller, 185-203. Zürich: Avenir Suisse.

McCall, Leslie. 2005. Managing the Complexity of Intersectionality. Signs (2005), 30(3): 1771-1800.

Ministère de l'Education Nationale et de la Formation Professionnelle/Ministère de la Santé/Universität Karlsruhe. 2006. Gesundheit, motorische Leistungsfähigkeit und körperlich-sportliche Aktivität von Kindern und Jugendlichen in Luxemburg. Untersuchung für die Altersgruppen 9, 14 und 18 Jahre. Abschlussbericht zum Forschungsprojekt. Luxemburg.

Ministère de l'Education Nationale et de la Formation Professionnelle. 2007. Les chiffres clés de l'éducation nationale 2005/2006. Statistiques et indicateurs, année scolaire 2005/2006. Luxembourg.

Ministère de l'Egalité des Chances. 2006. Gleiche Rechte für Mädchen und Jungen, Frauen und Männer. Luxembourg.

Ministère de la Santé/Ministère de l'Education Nationale et de la Formation Professionnelle. 2005. Das Wohlbefinden der Jugendlichen in Luxemburg im internationalen Vergleich. Luxemburg.

Ministère de la Santé/Ministère de l'Education Nationale et de la Formation Professionnelle. 2005. Das Wohlbefinden der Jugendlichen in Luxemburg, 5. und 6. Klasse, Grundschule. Luxemburg.

Ministère de la Santé/Ministère de l'Education Nationale et de la Formation Professionnelle. 2002. Das Wohlbefinden der Jugendlichen in Luxemburg. Luxemburg.

Nassehi, Armin. 1995. Der Fremde als Vertrauter. Soziologische Beobachtungen zur Konstruktion von Identitäten und Differenzen. Kölner Zeitschrift für Soziologie und Sozialpsychologie 47: 443-463.

N.N. 2008. 1. Fest der Grenzgänger - Grenzenlos feiern im Namen des interkulturellen Dialogs. Press release of the Luxembourg Ministry for Culture, Tertiary Education and Research of 26.09.2008. 
Park, Robert. 1974. Human Migration and the Marginal Man. In Collected Papers of Robert Ezra Park, vol. 1, 345-356. New York: Arno Press.

Pries, Ludger. 2008. Die Transnationalisierung der sozialen Welt. Frankfurt/M.: Suhrkamp.

Poulain, Jean-Pierre. 2002. Manger aujourd'hui. Attitudes, normes et pratiques. Paris: Private.

Reckinger, Rachel. 2008. Les pratiques discursives oenophiles entre normativité et appropriation. Contribution à une sociologie des cultures alimentaires: 2 volumes, PhD dissertation in Sociology. Marseille: Ecole des Hautes Etudes en Sciences Sociales.

Rose, Nicolas. 1999 [1989]. Governing the Soul. The Shaping of the Private Self. London: Free Association Books.

Reckwitz, Andreas. 2004. Die Kontingenzperspektive von Kultur. Kulturbegriffe, Kulturtheorien und das kulturwissenschaftliche Forschungsprogramm. In Handbuch der Kulturwissenschaften. Themen und Tendenzen, ed. Friedrich Jaeger and Jörn Rüsen, 1-20 Stuttgart: Metzler.

Reckwitz, Andreas. 2001. Multikulturalismustheorien und der Kulturbegriff: Vom Homogenitätsmodell zum Modell kultureller Interferenzen. Berliner Journal für Soziologie, volume 2, edition 11: 179-200.

Reuter, Julia and Matthias Wiesner. 2008. Soziologie im Zwischenraum: Grenzen einer transdifferenten Perspektive. In Kulturelle Differenzen begreifen. Das Konzept der Transdifferenz aus interdisziplinärer Sicht, ed. Lars Allolio-Näcke and Britta Kalscheuer, 129-143. Frankfurt/M.: Campus.

Reuter, Julia. 2002. Ordnungen des Anderen. Zum Problem des Eigenen in der Soziologie des Fremden. Bielefeld: transcript.

Rölli, Marc. 2006. Gilles Deleuze: Kultur und Gegenkultur. In Kultur. Theorien der Gegenwart, ed. Stephan Moebius, Dirk Quadflieg, 30-41. Wiesbaden: VSVerlag.

Rutherford, Jonathan. 1990. The Third Space. Interview with Homi Bhabha. In Identity: Community, Culture, Difference, ed. Jonathan Rutherford, 207-221. London: Lawrence and Wishart.

Scholliers, Peter, ed. 2001. Food, Drink and Identity. Cooking, Eating and Drinking in Europe since the Middle Ages. Oxford \& New York: Berg.

Schütz, Alfred. 1972. Gesammelte Aufsätze. Band 2: Studien zur soziologischen Theorie, ed. Arvid Brodersen. Den Haag: Nijhoff.

Schütz, Alfred. 1971. Der Fremde. Ein sozialpsychologischer Versuch. In Gesammelte Aufsätze. Band 2, 53-69. Den Haag: Martinus Nijhof.

Simmel, Georg. 1908. Soziologie. Untersuchungen über die Formen der Vergesellschaftung. Duncker \& Humblot: Berlin.

Ståhl, Timo, Matthias Wismar, Eeva Ollila, Eero Lahtinen and Kimmo Leppo, ed. 2006. Health in All Policies. Prospects and Potentials. Ministry of Social Affairs and Health, Finland \& European Observatory on Health Systems and Policies (http://www.euro.who.int/document/E8926o.pdf). 
STATEC. 2009. L'économie luxembourgeoise. Un kaléidoscope 2008. Luxembourg.

STATEC. 2009. Le secteur public. Economie et Statistiques, Working papers du STATEC 34.

Stichweh, Rudolf. 2005. Inklusion und Exklusion. Studien zur Gesellschaftstheorie. Bielefeld: transcript.

Wagener, Yolande. 2008. Promotion de la santé au Luxembourg. Promotion \& Education, Hors-Série Promotion de la santé: Besoin de recherche francophone et perspectives, $\mathrm{n}^{\circ}$ 1: 22-25.

Weischer, Christoph. 2007. Sozialforschung. Weinheim: Beltz.

Welsch, Wolfgang. 2005. Auf dem Weg zu transkulturellen Gesellschaften. In Differenzen anders denken. Bausteine zu einer Kulturtheorie der Transdifferenz, ed. Lars Allolio-Näcke, Britta Kalscheuer and Arne Manzeschke, 314-341. Frankfurt/M.: Campus.

World Health Organisation Europe (WHO). 1999. Santé 21. La politique-cadre de la Santé pour tous dans la Région européenne de l'OMS. Série européenne de la Santé pour tous, $n^{\circ} 6$.

World Health Organisation Europe (WHO). 2008. Inequalities in Young People's Health. Health Behaviour in School-Aged Children (HBSC). International Report from the 2005/2006 Survey. Health policy for children and adolescents, $\mathrm{n}^{\circ} 5$. 


\section{Aus:}

\section{IPSE (ed.): Doing Identity in Luxembourg. Subjective Appropriations - Institutional Attributions - Socio-Cultural Milieus. Bielefeld, transcript, 2011.}

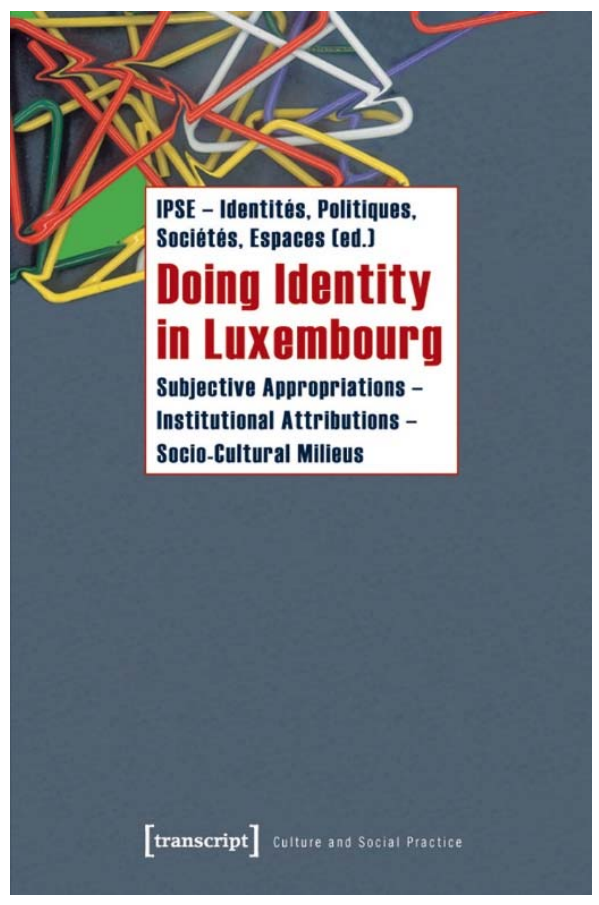

This empirical study provides insights about a society that has hitherto largely eluded scientific investigation and observes the processes of identity construction in globalised conditions. The interdisciplinary team of authors exposes the processes of subjective appropriations and institutional attributions at work in the fields of languages, spaces, perceptions of self and others as well as everyday cultures, and identifies for the first time socio-cultural milieus in the Grand Duchy. The findings of the three-year research project uncover the ambivalences and dynamics of a multicultural and multilingual society. 


\section{Content}

I. Preface $\mid 7$

Rachel Reckinger, Christian Schulz, Christian Wille

2. Researching Identity Constructions $\mid 11$

Rachel Reckinger, Christian Wille

2.1 A theoretical-conceptional approach to identities $\mid 11$

2.2 Methodology and Interdisciplinary Collaboration | 24

2.3 References | 35

3. Socio-Cultural Milieus in Luxembourg | 39

Wilhelm Amann, Fernand Fehlen, Georg Mein

3.1 Changing Social Structures. From the vertically orientated concept of stratification to the horizontally diversified milieu landscape 39

3.2 Profiles of Socio-Cultural Milieus in Luxemburg | 50

3.3 Final remark $\mid 62$

3.3 References $\mid 62$

4. Languages and Identities $\mid 6_{5}$

Peter Gilles, Sebastian Sefla, Heinz Sieburg, Melanie Wagner

4.1 Introduction: Germanic/Romance Diglossia | 65

4.2 Key Survey Results Concerning the Linguistic Situation | 68

4.3 Controversies in Readers' Letters concerning the Linguistic Situation | 81

4.4 'Linguistic Landscape': Public Signage and Multilingualism | 93

4.5 Conclusion: Linguistic Polynomia as an Opportunity $\mid 103$

4.6 References $\mid 104$

5. Spaces and Identities $\mid 107$

Marion Colas-Blaise, Sylvie Freyermuth, Sonja Kmec,

Gian Maria Tore, Christian Schulz

5.1 Introduction: Geographic Discourses and Tourism Practice | 107

5.2 Between Seduction and Reality: Luxembourg City and its Discourses $\mid 110$

5.3 Representing and Revaluating the City: the Geo-Graphy and Visual Identity of Luxembourg City $\mid 120$ 
5.4 Between National Unity and Regional Individualism 'Sways the Heart of Luxembourg' | 125

5.5 The Image of Luxembourg as a 'Melting Pot' | 133

5.6 The "Greater Region" - Spatial Constructions between Desire and Reality | 144

5.7 Conclusion: Spatial Identities - Multiple Readings?| 155

5.8 References 158

6. Images and Identities $\mid 165$

Wilhelm Amann, Viviane Bourg, Paul Dell, Fabienne Lentz, Paul Di Felice, Sebastian Reddeker

6.1 Images of Nations as 'Interdiscourses'. Preliminary Theoretical Reflections on the Relation of 'Images and Identities': The Case of Luxembourg | 165

6.2 Symbolisms in the Media-Based Perceptions of Self and Others of Luxembourg $\mid 168$

6.3 The Superjhemp Saga - an Ideal Projection Screen 179

6.4 Collective Symbols and (New) Identity Options in Luxembourg's Advertising $\mid 190$

6.5 Decontextualising and Deconstructing Representations of Identity: an Analysis of the Works of Seven Photographers | 202

6.6 The Representation of Italian Immigrants in the Exhibition Catalogue Retour de Babel | 216

6.7 Conclusions: National Identities in a Post-national Age?|225

6.8 References $\mid 226$

\section{Everyday Cultures and Identities $\mid 233$}

Christel Baltes-Löhr, Agnes Prüm, Rachel Reckinger, Christian Wille

7.1 Introduction: On the Reciprocal Relevance of Everyday Cultures and Identity Constructions | 233

7.2 Permanent Performances: Gender in Motion | 238

7.3 'Good' Food. Oscillation between Political Concept and Individual Everyday Practice | 255

7.4 Cross-Border Workers as Familiar Strangers | 271

7.5 Conclusions: Identities and Ambivalences of Everyday Cultures $\mid 283$

7.6 References $\mid 285$

8. Identity Constructions in Luxembourg | 291

Rachel Reckinger, Christian Wille, Christian Schulz

Authors | 295 